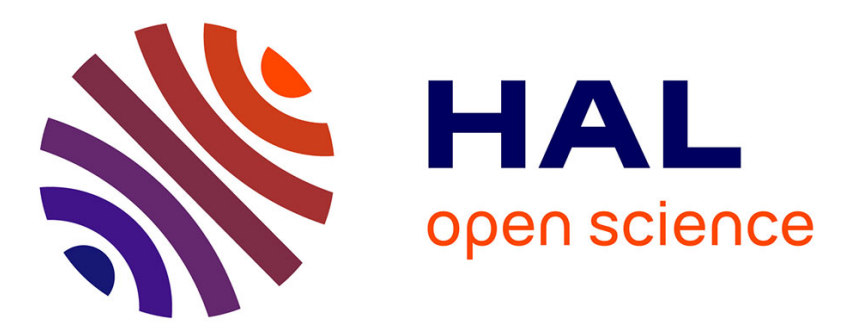

\title{
Energy performance and economic analysis of a TIM-PCM wall under different climates
}

Farah Souayfane, Pascal Henry Biwole, Farouk Fardoun, Patrick Achard

\section{To cite this version:}

Farah Souayfane, Pascal Henry Biwole, Farouk Fardoun, Patrick Achard. Energy performance and economic analysis of a TIM-PCM wall under different climates. Energy, 2019, 169, pp.1274-1291. hal-01995829

\section{HAL Id: hal-01995829 \\ https://hal.uca.fr/hal-01995829}

Submitted on 13 Oct 2021

HAL is a multi-disciplinary open access archive for the deposit and dissemination of scientific research documents, whether they are published or not. The documents may come from teaching and research institutions in France or abroad, or from public or private research centers.
L'archive ouverte pluridisciplinaire HAL, est destinée au dépôt et à la diffusion de documents scientifiques de niveau recherche, publiés ou non, émanant des établissements d'enseignement et de recherche français ou étrangers, des laboratoires publics ou privés. 


\title{
Energy Performance and Economic Analysis of a TIM-PCM wall Under Different Climates
}

\author{
Farah Souayfane $^{\mathrm{a}, \mathrm{b}}$, Pascal Henry Biwole ${ }^{\mathrm{c}, \mathrm{d}}$ Farouk Fardoun ${ }^{\mathrm{b}, \mathrm{e}}$ \\ (a) Université Cote d'Azur, J.A. Dieudonné Laboratory, UMR CNRS 7351, 06108 Nice, France \\ (b) Université Libanaise, Centre de Modélisation, Ecole Doctorale des Sciences et Technologie, Hadath, \\ Liban \\ (c) Université Clermont Auvergne, CNRS, SIGMA Clermont, Institut Pascal, F-63000 Clermont-Ferrand, \\ France

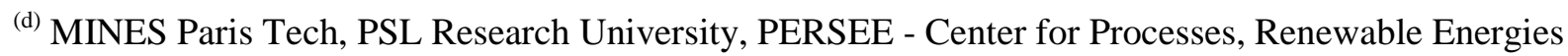 \\ and Energy Systems, CS 10207, 06904 Sophia Antipolis, France \\ (e) Faculty of Technology, Department GIM, Lebanese University, Saida, Lebanon
}

\begin{abstract}
The application of an innovative translucent superinsulated latent heat storage wall, combining transparent insulation material and phase change materials (TIM-PCM wall), on the envelope of a typical office under different climates is evaluated. Energy and economic analysis related to this application are presented. The simulation process is carried out using an experimentally validated numerical model. The results show that the incorporation of the TIM-PCM wall, on the south orientation, is more efficient than the use of a double-glazed in all considered climates. The optimum TIM-PCM wall area is evaluated economically through life-cycle cost and payback period analysis. The purpose is to ensure an effective performance of the wall in each climate and at the same time to ensure an economic viability. The results show that, in polar and subarctic climates, the application of the TIM-PCM wall has a high economic value and the investment appears to be attractive, the payback period being 10.5 years and 7.8 years respectively. In Dras (continental climate), the use of the wall is found economically unfeasible due to low energy prices and high discount rates. At current prices, the TIM-PCM wall investment in Sacramento (Mediterranean climate) and Toronto (Humid continental) does not offer economic benefits.
\end{abstract}


Keywords: TIM-PCM wall, energy performance, climatic zones, economic analysis, office building envelope. 


\section{Nomenclature}

$\begin{array}{lll}\text { COP } & \text { Coefficient of performance } & \\ \text { Cp } & \text { Specific heat capacity } & (\mathrm{J} / \mathrm{kg} \cdot \mathrm{K}) \\ \text { CSTB } & \text { Scientific and technical center for building research } & \\ \text { EC } & \text { Energy cost } & (\$) \\ \mathrm{e}_{\mathrm{i}} & \text { Experimental values } & \\ \mathrm{EN} & \text { European norm } & (\$) \\ \text { ESC } & \text { Energy savings cost } & \\ \mathrm{f}_{1} & \text { Liquid fraction } & (\mathrm{m}) \\ \mathrm{H} & \text { Height of the vertical surface } & \left(\mathrm{W} / \mathrm{m}^{2} \mathrm{~K}\right) \\ \mathrm{h}_{\text {in }} & \text { Indoor convective coefficient } & \left(\mathrm{W} / \mathrm{m}^{2} \mathrm{~K}\right) \\ \mathrm{h}_{\text {out }} & \text { Outdoor convective coefficient }\end{array}$

HVAC Heating, ventilation and air conditioner

IC Initial cost

$\mathrm{k} \quad$ Thermal conductivity

$(\mathrm{W} / \mathrm{m} \cdot \mathrm{K})$

LCC Life cycle cost

$\mathrm{L}_{\mathrm{H}} \quad$ Latent heat of fusion

$\mathrm{N} \quad$ Lifetime

(years)

PCM Phase change materials

PERSEE center for processes, renewable energies and energy systems

PP Payback period

PRMSE Percentage root mean square error

PWF Present worth factor

$\mathrm{Q}_{\text {sol-trans }} \quad$ Transmitted solar radiation

$\left(\mathrm{W} / \mathrm{m}^{2}\right)$

r Discount rate

RMSE Root mean square error

$\mathrm{S}_{\mathrm{i}} \quad$ Simulated values

$\mathrm{T}_{\text {air }} \quad$ Outdoor air temperature

TIM Transparent insulation material 


$\begin{array}{lll}\mathrm{T}_{\mathrm{m}} & \text { Melting temperature } & \text { ( } \square \mathrm{C}) \\ \mathrm{T}_{\text {evap }} & \text { Evaporating temperature } & (\square \mathrm{C}) \\ \mathrm{T}_{\text {cond }} & \text { Condensing temperature } & (\square \mathrm{C}) \\ \mathrm{v} & \text { Wind velocity } & (\mathrm{m} / \mathrm{s})\end{array}$

\section{Greek letters}

$\emptyset_{\mathrm{LW}, \text { in }}$ Radiative heat exchange with the indoor environment $\quad\left(\mathrm{W} / \mathrm{m}^{2}\right)$

$\emptyset_{\mathrm{LW}, \text { out }}$ Radiative heat exchange with the outdoor environment $\left(\mathrm{W} / \mathrm{m}^{2}\right)$

$\emptyset_{\text {cond }}$ Conductive heat flux $\left(\mathrm{W} / \mathrm{m}^{2}\right)$

$\emptyset_{\text {sol }}$ Radiative source term $\left(\mathrm{W} / \mathrm{m}^{2}\right)$

$\alpha \quad$ Thermal diffusivity $\quad\left(\mathrm{m}^{2} / \mathrm{s}\right)$

$\alpha \quad$ Solar absorptivity coefficient

$\beta \quad$ Thermal expansion coefficient $\quad(1 / \mathrm{K})$

$\Delta t \quad$ Time increment

$\varepsilon \quad$ Surface emissivity

$\rho \quad$ Solar reflectivity coefficient

$\eta \quad$ Boiler efficiency $\quad(\%)$

$\lambda \quad$ wavelength $\quad(\mu \mathrm{m})$

$v \quad$ Viscosity $\quad\left(\mathrm{m}^{2} / \mathrm{s}\right)$

$\rho \quad$ Density $\quad\left(\mathrm{kg} / \mathrm{m}^{3}\right)$

$\sigma \quad$ Extinction coefficient

$\tau \quad$ Solar transmissivity coefficient

\section{Subscripts and superscripts}

$\begin{array}{ll}\mathrm{c} & \text { Cooling } \\ \text { conv } & \text { conventional } \\ \mathrm{e} & \text { Electricity } \\ \text { enh,p } & \text { enhanced at node } \mathrm{p} \\ \mathrm{h} & \text { Heating } \\ \text { in } & \text { indoor }\end{array}$




$\begin{array}{ll}\text { ng } & \text { Natural gas } \\ \text { sol } & \text { solar } \\ \text { surf } & \text { surface } \\ \text { W, e } & \text { west, east interface } \\ \text { W, E, P } & \text { west, east, center node }\end{array}$




\section{Introduction}

Nowadays, reducing the total energy demand of the world is a crucial challenge, due to global warming, climate change effects, energy crisis, and environmental issues. Building sector contributes to a great part of the world's energy consumption [1], mainly due to the heating and cooling demands. Thus, one of the most important ways of reducing the total global energy consumption is to decrease the energy used in HVAC systems in buildings. One promising solution is the integration of latent thermal energy storage systems based on phase change materials in the building envelope. Phase change materials can store (during melting) and release (during solidification) large amounts of energy at an almost constant temperature. Consequently, they can enhance building energy performance, decrease building energy use, reduce peak heating and cooling loads and improve thermal comfort [2]-[6]. However, the workability of passive PCM application in buildings depends on the diurnal temperature variations that ensure the PCM cycling. Thus, an effective use of PCM in buildings requires an appropriate selection of thermo-physical properties, quantity, and position of the PCM. Many studies were conducted to find optimum PCM thickness, melting temperature, and location under different climate conditions [7]-[9]. However, in addition to energy-saving and thermally efficient materials, the ever-growing construction industries worldwide require environmentally friendly and inexpensive materials [10].

Trombe walls with integrated phase change materials are a passive solar technique that has shown great potentialities [11]-[15]. During the day, this wall is heated due to the incident solar radiation, melting the PCM. At night, when the outdoor temperature falls below the phase change temperature, the heat stored by the PCM is released, warming the building. However, this technique induces a loss of visual daylight comfort because it is opaque. Many studies focus on the integration of PCM into a transparent component [16] [17] [18] [19] [20] [21] so that the PCM is directly exposed to the solar radiation which improves the PCM charge process, providing daylighting at the same time. Although the integration of PCM in transparent or opaque building envelope has shown a positive impact on annual cooling and heating loads and indoor thermal comfort in various climate zones, there are still technical, environmental, and economic barriers to be addressed.

Kyriaki et al. [22] analyzed the state of the art of the existing research on the environmental and economic performance of the application of PCM in buildings by using life cycle analysis (LCA) 
and life cycle cost analysis (LCCA) methodologies. It was concluded that to minimize the overall environmental impact, the use of PCM and the useful life of the building should be maximized. In addition, they concluded that very few studies are found about the economic assessment of PCM, based on life-cycle cost analysis. And that the application of PCM does not seem to be economically viable because of their high initial investment cost. Baniassadi et al. [23] conducted an economic optimization of the thickness of the insulation and the PCM layer of a residential building for different climatic regions of Iran using life-cycle cost analysis (LCCA). The results showed that with the current economic situation of the country and current energy prices, insulation layers are more cost-effective than phase change materials. This is due to the relatively high price of the BioPCM material which makes its use not economically viable. Akeiber et al. [10] evaluated the thermal performance and economy of a newly developed PCM extracted from Iraqi crude petroleum waste product. Experiments showed that the room without PCM encapsulation consumes higher energy to maintain the indoor temperature at $24 \square \mathrm{C}$. The energy economy of the PCM incorporated room is simply evaluated by comparing the estimated electricity cost with the building that contains the traditional air conditioning system. They found that PCM encapsulation leads to a great amount of electrical energy saving and maintains better thermal comfort in hot and dry climate condition. Panayiotou et al. [24] evaluated the application of macroencapsulated PCM on the envelope of a typical dwelling in the Mediterranean region. The optimum case, achieving maximum energy savings, was combining the PCM with a common thermal insulation. The results showed that the maximum yearly energy savings obtained by the combined case are $66.2 \%$. The results were also economically evaluated using life-cycle cost (LCC) analysis. It was shown that the use of PCM alone is not a very attractive solution in financial terms. This is due to the combination of high initial cost and low annual saving cost which results in a long payback time of $14 \frac{1 / 2}{2}$ years. When the PCM is combined with thermal insulation, the payback period is reduced to $7 \frac{1 / 2}{2}$ years. Kosny et al. [25] investigated a cost analysis of simple PCM-enhanced building envelopes in southern U.S. climates. They found that dispersed PCM in wall and attic applications can be cost-effective and payback periods for their building applications can be less than 10 years. Also, the best candidates for these applications are found where electricity cost is higher than $\$ 0.20 / \mathrm{kWh}$ and in U.S. locations with cooling degree days CDDs higher than 30000. Bland et al. [26] showed in their study the breakdown of the financial viability of installing a PCM system into a UK home. They found that an ideal PCM 
system installed into a residential building will need a service life of at least 25 years to make it viable. The PCM systems must provide significant energy savings before they become attractive to commercial purchasers. Chan [27] evaluated the thermal and the energy performance of a typical residential building with PCM integrated external walls in Hong Kong. They found that the building integrated with PCM is economically unfeasible in Hong Kong, mainly due to the expensive capital cost of PCM wallboard with a payback period of 91 years. For economic analysis, Mi et al. [28] used the static and the dynamic payback period approach to evaluate the application of PCM in a typical office building in five different climates in China. They found that the energy savings resulting from PCM application were the best for the office building located in a severely cold climate, followed by cold region. From the economic analysis, the application of PCM in cities having severe or cold winter showed high economic value and the investment appeared to be attractive. However, at current prices, the PCM investment in cities having a mild and warm climate, cannot be recovered and do not offer economic benefits. Wahid et al [29] highlighted the feasibility of PCM utilization in the households. They found that PCM could be extensively used in building structures to reduce the electricity demand. Sun et al. [30] presented an energy and economic analysis related to the application of phase change materials boards (PCMBs) in building enclosures during the cooling season. Following a simple payback period evaluation, they found that the use of PCMBs can be possibly cost-effective in occupied buildings for moderate temperature climates. Chaiyat [31] concluded that integration of PCM balls within the evaporator of the air-conditioner was more beneficial than the normal airconditioner based on energy efficiency and economic results.

From all the above mentioned, it can be stated that: (1) the studies on economic analysis of building integrated with PCM are not comprehensive and more studies should be conducted to evaluate the economic performance of the use of PCM in buildings, (2) economic analyses related to the application of PCM in buildings are conducted based on a life-cycle cost evaluation or based on a payback period evaluation (3) the PCM systems must provide significant energy savings before they become attractive to commercial purchase, (4) the economic feasibility of PCM depends on climatic conditions, energy costs, country economic situation, (5) most previous studies found that the application of PCM is not economically viable mainly due to the expensive investment costs compared to the expected energy savings. 
The present paper investigates an innovative passive solar wall, referred to as TIM-PCM wall, providing at the same time very high insulation, latent heat storage, and daylighting. The wall is composed of a glazing facing the outside, a gap filled with high insulation silica aerogels materials (transparent insulation material-TIM), and glass bricks filled with a eutectic PCM on the inside. The whole wall is translucent. The energy and economic performance of the incorporation of the TIM-PCM wall in an office room envelope are investigated under different climates via an experimentally validated numerical model for a whole year. The annual heating and cooling energy loads are determined for a conventional office room equipped with an insulated double-glazed window and then compared with those of the correspondent office room equipped with a TIM-PCM wall at the south orientation. Energy savings due to the use of TIMPCM are evaluated. Then, the optimum TIM-PCM wall area is assessed economically for each climate through life-cycle cost and payback period analysis. The aim is to ensure a good functioning of the TIM-PCM wall in each climate and at the same time ensure economic feasibility. Noting that, The TIM-PCM wall is an innovative solar wall, its impact on the building thermal behavior has never been studied numerically under different climates for an annual basis. Also, the feasibility of the wall application from an economic point of view has never been studied. The wall area was also optimized depending on the climate for the first time. In addition, in the literature, there is a lack of studies that evaluate the economic performance of the use of PCM in buildings. The effective PCM system, in terms of reducing heating or cooling loads, does not necessarily mean that this system can be applicable to real life constructions, it must provide significant energy savings before it becomes attractive to commercial purchase. The current study represents a starting point and should be continued in future, the purpose is not only to ensure an effective performance of the PCM application but also to ensure an economic viability.

\section{Methodology}

\subsection{Description of simulated building}

The energy performance of a single-story office building equipped with TIM-PCM wall is studied (Figure 1). The office has a height of $2.8 \mathrm{~m}$ and a total floor area of $32 \mathrm{~m}^{2}$ with a slab-ongrade foundation. The ground floor is highly insulated assuming a small heat exchange occurring between the office room and the ground. The walls construction composition and the thermophysical properties of used materials are summarized in Table 1 and Table 2. The conventional office room is equipped with an insulated double-glazed window on the south wall of a total area 
of $11.2 \mathrm{~m}^{2}$. The double glazing with krypton insulation of thickness $4 / 16 / 4$ has a $U$ value of 0.86 $\mathrm{W} / \mathrm{m}^{2} \mathrm{~K}$ and a $\mathrm{g}$ value of 0.598 . The annual heating and cooling loads are determined for the conventional office room for different climate conditions and then compared through simulation with those of the correspondent PCM-enhanced office room, equipped with a TIM-PCM wall at the south orientation.

The TIM-PCM wall shown in Figure 2 is composed, from outside to inside, of a glass pane having a thickness of $0.8 \mathrm{~cm}$, a $4 \mathrm{~cm}$ thick bed of granular silica aerogel, and a eutectic of fatty acids as PCM, filled in glass bricks of dimension $19 \mathrm{~cm} \times 19 \mathrm{~cm} \times 5 \mathrm{~cm}$. More details about the TIM-PCM wall can be found in [32], [33]. The thermo-physical and optical properties of the used PCM, the silica aerogel, and the glass are summarized in Table 1 to Table 5. In the simulation, the area of the insulated double-glazed window and the TIM-PCM wall is varied from $0 \mathrm{~m}^{2}$ to $7.532 \mathrm{~m}^{2}$. Otherwise, the ratio of the double-glazing area over the total south wall area varies between $0 \%$ and $67 \%$, same for the TIM-PCM wall (Table 6).

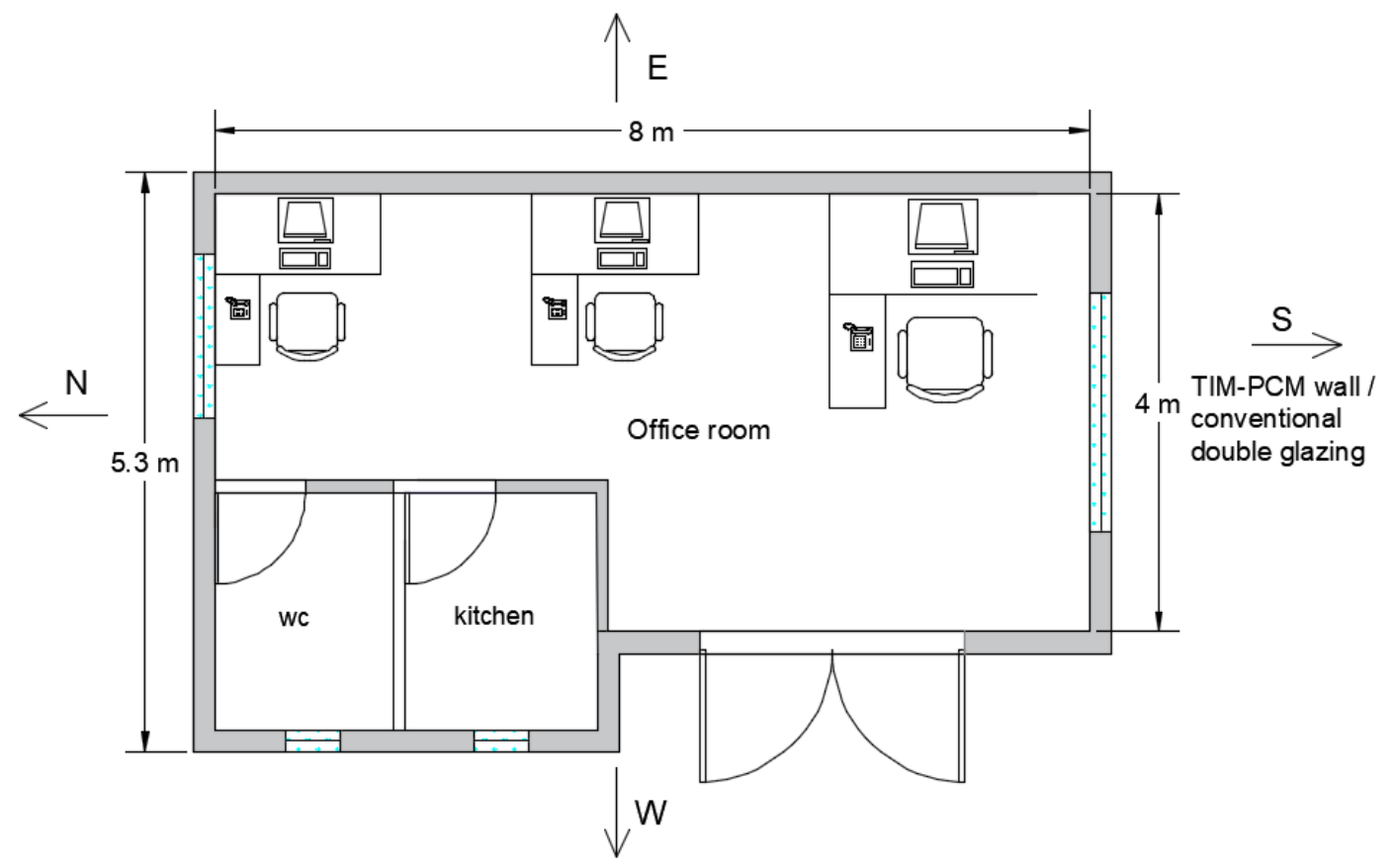

Figure 1: Typical plan of a simple office room. 

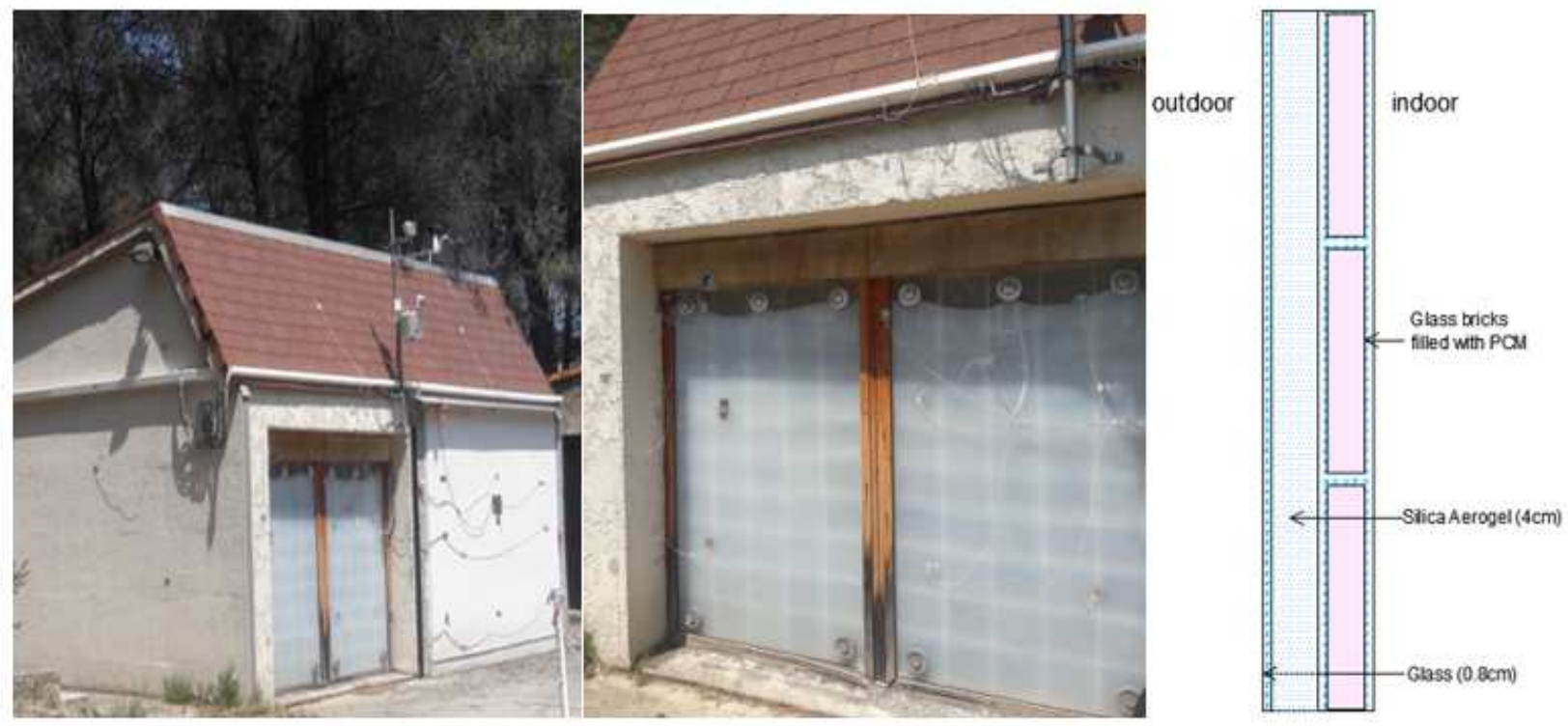

Figure 2: TIM-PCM wall from the outside and Schematic of the TIM-PCM wall composition

Table 1: office room walls construction

\begin{tabular}{|c|c|c|c|}
\hline Element & Construction (inside to outside) & Thickness (m) & $\mathbf{U}$ value $\left(\mathrm{W} / \mathbf{m}^{2} \mathbf{K}\right)$ \\
\hline \multirow{3}{*}{ External walls } & plasterboard & 0.015 & \multirow{3}{*}{0.419} \\
\hline & Glass wool & 0.085 & \\
\hline & concrete & 0.20 & \\
\hline \multirow{3}{*}{ Partitions } & plaster & 0.013 & \multirow{3}{*}{0.241} \\
\hline & Glass wool & 0.16 & \\
\hline & plaster & 0.013 & \\
\hline \multirow{5}{*}{ Roof } & plasterboard & 0.013 & \multirow{5}{*}{0.163} \\
\hline & Glass wool & 0.16 & \\
\hline & Wooden plate & 0.012 & \\
\hline & Mousse phenol-formol & 0.06 & \\
\hline & Wooden plate & 0.012 & \\
\hline \multirow{3}{*}{ Floor } & tiles & 0.015 & \multirow{3}{*}{0.189} \\
\hline & concrete & 0.15 & \\
\hline & Expanded polystyrene & 0.08 & \\
\hline
\end{tabular}

Table 2: Thermo-physical properties of the test room materials

\begin{tabular}{lccc}
\hline \multicolumn{1}{c}{ Materials/properties } & $\begin{array}{c}\text { Thermal conductivity } \\
(\mathbf{W} / \mathbf{m} . \mathbf{K})\end{array}$ & $\begin{array}{c}\text { Specific heat } \\
(\mathbf{J} / \mathbf{k g . K})\end{array}$ & Density $\left(\mathbf{k g} / \mathbf{m}^{\mathbf{3}}\right)$ \\
\hline plasterboard & 0.32 & 800 & 790 \\
Glass wool & 0.041 & 840 & 12
\end{tabular}


concrete

Mousse phenol-formol

Wooden plate

Expanded polystyrene

tiles
2.1

0.032

0.18

0.04

1
800

1255

1700

1380

1000
2400

32

780

25

2400

Table 3: Thermo-physical properties of the fatty acids eutectic [32]

\begin{tabular}{cc}
\hline Property & value \\
\hline $\mathrm{k}_{\mathrm{s}}(\mathrm{W} / \mathrm{m} \cdot \mathrm{K})$ & 0.182 \\
$\mathrm{k}_{\mathrm{l}}(\mathrm{W} / \mathrm{m} \cdot \mathrm{K})$ & 0.182 \\
$\mathrm{~L}_{\mathrm{H}}(\mathrm{J} / \mathrm{kg})$ & 152000 \\
$\mathrm{C}_{\mathrm{s}}(\mathrm{J} / \mathrm{kg} \cdot \mathrm{K})$ & 1670 \\
$\mathrm{Cp}_{\mathrm{l}}(\mathrm{J} / \mathrm{kg} \cdot \mathrm{K})$ & 2090 \\
$\rho_{\mathrm{s}}\left(\mathrm{kg} / \mathrm{m}^{3}\right)$ & 960 \\
$\rho_{\mathrm{l}}\left(\mathrm{kg} / \mathrm{m}^{3}\right)$ & 884 \\
$\mathrm{Tm}\left({ }^{\circ} \mathrm{C}\right)$ & 21.3 \\
$\alpha\left(\mathrm{m}^{2} / \mathrm{s}\right)$ & $9.85 \times 10^{-8}$ \\
$v\left(\mathrm{~m}^{2} / \mathrm{s}\right)$ & $11 \times 10^{-6}$ \\
$\beta(1 / \mathrm{K})$ & $3.1 \times 10^{-3}$ \\
\hline
\end{tabular}

Table 4: Optical properties of the fatty acids eutectic [32]

\begin{tabular}{llcc}
\hline & & $\tau \%$ & $\rho \%$ \\
\hline \multirow{2}{*}{ Liquid state } & Energetic $(0.1 \mu \mathrm{m}<\lambda<100 \mu \mathrm{m})$ & 90 & 5 \\
& Optical $(0.38 \mu \mathrm{m}<\lambda<0.78 \mu \mathrm{m})$ & 78 & 6 \\
\hline \multirow{2}{*}{ Solid state } & Energetic $(0.1 \mu \mathrm{m}<\lambda<100 \mu \mathrm{m})$ & $\approx 0$ & 53 \\
& Optical $(0.38 \mu \mathrm{m}<\lambda<0.78 \mu \mathrm{m})$ & $\approx 0$ & 56 \\
\hline
\end{tabular}

Table 5: Thermo-physical and optical properties of glass and Silica aerogel

\begin{tabular}{ccc}
\hline properties/Materials & glass & Silica aerogel \\
\hline Thickness $(\mathrm{cm})$ & 0.8 & 4 \\
$\mathrm{k}(\mathrm{W} / \mathrm{m} . \mathrm{K})$ & 1 & $0.018($ at $25 \square \mathrm{C})$ \\
$\mathrm{Cp}(\mathrm{J} / \mathrm{kg} . \mathrm{K})$ & 840 & 1500 \\
$\rho\left(\mathrm{kg} / \mathrm{m}^{3}\right)$ & 2700 & 100 \\
$\tau \%$ & 80 & 57 \\
$\alpha \%$ & 12 & 10 \\
\hline
\end{tabular}

Table 6: Different dimensions of the TIM-PCM wall to be studied

\begin{tabular}{ccccc}
\hline Bricks number & TIM-PCM wall area $\left(\mathbf{m}^{\mathbf{2}}\right)$ & PCM volume $\left(\mathbf{m}^{\mathbf{3}}\right)$ & $\begin{array}{c}\text { Rest of wall area } \\
\left(\mathbf{m}^{\mathbf{2}}\right)\end{array}$ & $\begin{array}{c}\text { (TIM-PCM wall } \\
\text { area / total wall } \\
\text { area) }(\%)\end{array}$ \\
\hline 0 & 0 & 0 & 11.2 & 0 \\
40 & 1.5064 & 0.041344 & 8.65 & $13.5 \%$ \\
90 & 3.3894 & 0.093024 & 6.77 & $30 \%$ \\
\hline
\end{tabular}




\begin{tabular}{lcccc}
\hline 140 & 5.2724 & 0.144704 & 4.89 & $47 \%$ \\
200 & 7.532 & 0.20672 & 2.63 & $67 \%$ \\
\hline
\end{tabular}

Regarding internal heat gains (Table 4-7), the office room is occupied by three persons in light work office activity with a constant metabolic rate of $115 \mathrm{~W} /$ person. To simulate a real-lifestyle, the office is considered occupied during the weekdays from 8 a.m. till 12 p.m. and from 2 p.m. till 6 p.m. and unoccupied during weekends.

The following scenario is adopted:

- The heating system is always available to maintain the indoor air temperature at a predefined setpoint level. The heating set-point schedule is the same as that of the French thermal regulations "RT 2012", heating set-point is set at $19^{\circ} \mathrm{C}$ for occupied time and at $16^{\circ} \mathrm{C}$ for unoccupied times [34].

- The cooling set-point is set at $26^{\circ} \mathrm{C}$ for occupied time and off for unoccupied times.

- The infiltration rate is taken 0.4 ACH (ASHRAE Fundamentals Handbook [35])

- The European Lighting Standard EN12464-1 [36], requires an illuminance of 500 lux in working areas. The artificial lighting is not always ON since the TIM-PCM wall allows daylighting.

Table 7: Internal heat gains in the office room (ASHRAE Fundamentals Handbook (SI) [35])

\begin{tabular}{lc}
\hline \multicolumn{1}{c}{ Gains } & Value \\
\hline 3 persons & $115 \mathrm{~W}$ of which $45 \mathrm{~W}$ radiative $70 \mathrm{~W}$ convective \\
3 Computers & $20 \mathrm{~W}$ of which $15 \%$ radiant and $85 \%$ convective \\
One printer & $35 \mathrm{~W}$ of which $20 \%$ radiant and $80 \%$ convective \\
3 Phones / faxes & $15 \mathrm{~W}$ of which $30 \%$ radiant and $65 \%$ convective \\
Microwave oven $28 \mathrm{~L}$ & $400 \mathrm{~W}$ of convective gain \\
Small refrigerator & $310 \mathrm{~W}$ of convective gain \\
\hline
\end{tabular}

\subsection{Investigated climates}

The main objective of this work is to evaluate the energy performance of the TIM-PCM wall and to find the optimum wall configuration in different places around the world. Therefore, six climates for different cities were considered according to the Köppen-Geiger classification [37]. Table 8 shows the description of the different selected climates for this study as well as the latitude, the longitude and the elevation for each city. Since the main purpose of the solar TIMPCM wall is to provide heating to the indoor environment, most of the climates are chosen with mild, cold or severe winter season and the climate classifications A (tropical) and B (arid) are 
excluded from the study. The weather data files are extracted from TRNSYS Meteonorm library.

Table 9 presents some major weather characteristics for each climate.

Table 8: Selected locations and climate characteristics according to Köppen-Geiger classification [37]

\begin{tabular}{llccc}
\hline \multicolumn{1}{c}{ City } & \multicolumn{1}{c}{ Climate } & Latitude & Longitude & Elevation (m) \\
\hline $\begin{array}{l}\text { Sacramento, California, } \\
\text { (USA) }\end{array}$ & Mediterranean climate (Csa) & $38.5816^{\circ} \mathrm{N}$ & $121.4944^{\circ} \mathrm{W}$ & 9.1 \\
\hline Paris (France) & Oceanic climate (Cfb) & $48.8566^{\circ} \mathrm{N}$ & $2.3522^{\circ} \mathrm{E}$ & 36 \\
\hline Toronto (Canada) & Humid Continental (Dfa) & $43.6532^{\circ} \mathrm{N}$ & $79.3832^{\circ} \mathrm{W}$ & 76 \\
\hline Dras (India) & Continental (Dsb) & $34.4330^{\circ} \mathrm{N}$ & $75.7670^{\circ} \mathrm{E}$ & 3066 \\
\hline Kiruna (Sweden) & Continental subarctic (Dfc) & $67.8558^{\circ} \mathrm{N}$, & $20.2253^{\circ} \mathrm{E}$ & 530 \\
\hline Barentsburg (Norway) & Polar climate (ET) & $78.0648^{\circ} \mathrm{N}$ & $14.2335^{\circ} \mathrm{E}$ & 15 \\
\hline
\end{tabular}

Table 9: Some main weather characteristics for each climate

\begin{tabular}{lcccccc}
\hline \multicolumn{1}{c}{ City } & Sacramento & Paris & Toronto & Dras & Kiruna & Barentsburg \\
\hline \multicolumn{1}{c}{ Climate } & Csa & Cfb & Dfa & Dsb & Dfc & ET \\
\hline Max outdoor temperature $\left({ }^{\circ} \mathrm{C}\right)$ & 39.7 & 31.25 & 31.05 & 29.3 & 23.6 & 12.2 \\
\hline Min outdoor temperature $\left({ }^{\circ} \mathrm{C}\right)$ & -0.8 & -7.75 & -21.75 & -23.4 & -32.75 & -29.3 \\
\hline $\begin{array}{l}\text { Max incident solar radiation on southern } \\
\text { vertical plane }\left(\mathrm{W} / \mathrm{m}^{2}\right)\end{array}$ & 833.08 & 844.97 & 881.84 & 963.86 & 837.01 & 890.74 \\
\hline $\begin{array}{l}\text { Total yearly solar radiation on southern } \\
\text { vertical plane }\left(\mathrm{Kwh} / \mathrm{m}^{2} / \text { year }\right)\end{array}$ & 1148.54 & 751.48 & 946.92 & 1044.83 & 686.27 & 601.23 \\
\hline
\end{tabular}

In general, in cooling dominant climates (Köppen-Geiger classifications A and B) the optimum PCM melting temperature is closer to the maximum of $26^{\circ} \mathrm{C}$ (melting range of $24^{\circ} \mathrm{C}-28^{\circ} \mathrm{C}$ ), whereas in heating dominant climates (C and D) the optimum PCM melting is closer to the minimum of $20^{\circ} \mathrm{C}$ (melting range of $18^{\circ} \mathrm{C}-22^{\circ} \mathrm{C}$ ) [9]. The eutectic fatty acids integrated into the glass bricks of the TIM-PCM wall having a phase change temperature of $21.3^{\circ} \mathrm{C}$ is appropriate for the chosen climates.

\subsection{Numerical model}

In this work, a one-dimensional numerical model is developed considering the effect of thermal bridges caused by the joints of the bricks. Mesh sensitivity analysis was carried out for the numerical model to make sure that the results are independent of the numerical domain. Finally, a total of 16 nodes were used, 2 for the glazing layer, 5 for the silica aerogel, 5 for PCM layer and 
2 nodes for each glass brick. The chosen discretized scheme shows good accuracy within a satisfactory computational time, and it is well-matched with other works evaluating the annual thermal performance of PCM applications in facades [38]-[40]. The unsteady energy equation is written for each node and solved numerically. The developed TIM-PCM wall model computes the temperature field and the solar radiation transmitted to the test cell through the wall at each time step, these outputs are then linked to TRNSYS to simulate the energy performance of the whole building. More details about the development of the numerical model can be found in [41]. For the TIM-PCM wall, the heat transfer includes different regions, which are the outer glazing, the silica aerogel insulation and the PCM filled in glass brick. The one-dimensional unsteady energy equation for glazing and insulation layer is given as

$\rho C_{p} \frac{\partial T}{\partial t}=k \frac{\partial^{2} T}{\partial x^{2}}+\emptyset_{s o l}$

Eq. 1

where $\rho$ is the density $\left(\mathrm{kg} / \mathrm{m}^{3}\right), C_{p}$ is the specific heat $(\mathrm{J} / \mathrm{kg} . \mathrm{K}), \mathrm{k}$ is the thermal conductivity $(\mathrm{W} / \mathrm{m} . \mathrm{K})$ and $\emptyset_{\mathrm{sol}}\left(\mathrm{W} / \mathrm{m}^{2}\right)$ is the absorbed solar radiation at the surface of the layer.

In the PCM layer, the heat transfer during phase change is done by conduction, natural convection in the liquid phase and shortwave radiation. The unsteady energy equation for PCM regions is given as [42]:

$\rho C_{p} \frac{\partial T}{\partial t}=\frac{\partial}{\partial x}\left(k \frac{\partial T}{\partial x}\right)-\rho L_{H} \frac{\partial f_{l}}{\partial t}+\emptyset_{s o l}$

Eq. 3

where $\emptyset_{\text {sol }}\left(\mathrm{W} / \mathrm{m}^{2}\right)$ is the absorbed solar radiation, in the layer, $L_{H}$ is the latent heat of fusion $(\mathrm{J} / \mathrm{kg})$ and $f_{l}$ is the liquid fraction.

The absorbed solar radiation $\emptyset_{\text {sol }}$, at a node $\mathrm{p}$ in the PCM layer, is then given as [17]:

$\emptyset_{\text {sol }}=\frac{Q_{\text {sol-trans }} \alpha_{P}}{N}$

Eq. 4

$Q_{\text {sol-trans }}$ is the transmitted solar radiation to the PCM layer calculated using equations given by Siegel [43], $\alpha_{\mathrm{P}}$ is the PCM absorption coefficient at the node $\mathrm{p}$ calculated using the equations proposed by Gowreesunker et al. to model combined phase change and radiation problems [17]. To solve the phase change problem, a fixed-grid modified "enthalpy" method is used, inspired by the work of Zivkovic et al. [44]. The convection in the liquid PCM is accounted for using the enhanced thermal conductivity approach together with the scaling theory [45] [46] [47]. The 
convection effect is only considered in the upper part of the PCM layer of height $\mathrm{z}_{1}$ and width $\mathrm{z}_{2}$, while the zone $\left(\mathrm{z}_{2} \cdot \mathrm{H}_{\mathrm{b}}\right)-\left(\mathrm{z}_{1} \cdot \mathrm{z}_{2}\right)$ is controlled by conduction. Therefore, an average enhanced conductivity for liquid nodes is used in the one-dimensional model expressed by:

$k_{e n h, p}=\frac{k_{l}\left[\left(\mathrm{z}_{2} \cdot \mathrm{H}_{\mathrm{b}}\right)-\left(z_{1} \cdot z_{2}\right)\right]+k_{l} \cdot N u_{z_{1}}\left(z_{1} \cdot z_{2}\right)}{\mathrm{z}_{2} \cdot \mathrm{H}_{\mathrm{b}}}$

Eq. 5

where $k_{e n h, p}$ is the liquid enhanced conductivity for the liquid PCM node $\mathrm{p}, \mathrm{H}_{\mathrm{b}}$ is the height of the glass brick filled with $\mathrm{PCM}$ and $\mathrm{Nu}_{\mathrm{z}}$ is the Nusselt number correlation given by Berkovsky and Polevikov [48]. More details can be found in the reference [33].

The heat balance on the outside surface is given by [49]:

$\rho c_{p} \frac{\Delta x}{2} \frac{\partial T}{\partial t}=\emptyset_{\text {cond }}(t)+\emptyset_{\mathrm{LW}, \mathrm{out}}(t)+\emptyset_{\text {conv,out }}(t)+\emptyset_{\text {sol }}(t)$

Eq. 6

where, $\emptyset_{\text {cond }}(t)$ is the conductive heat flux in $\left(W / m^{2}\right)$ is given as:

$\emptyset_{\text {cond }}(t)=\frac{k}{\Delta x}\left(T_{s+\Delta x}-T_{\text {surf }}\right)$

and $\emptyset_{\text {sol }}\left(W / \mathrm{m}^{2}\right)$ is the solar absorption flux at the surface expressed by:

$\emptyset_{\text {sol }}(t)=\alpha Q_{\text {sol-total }}$

Eq. 8

$\emptyset_{\mathrm{LW}, \text { out }}(t)$ and $\emptyset_{\text {conv,out }}(t)$ are respectively the radiative heat exchange $\left(\mathrm{W} / \mathrm{m}^{2}\right)$ with the outdoor environment and the convective heat flux with the outside.

the radiative heat exchange with the outdoor environment is given as follow:

$\emptyset_{L W, \text { out }}=h_{r, \text { grd }} F_{\text {grd }}\left(T_{\text {grd }}-T_{\text {surf }}\right)+h_{r, s k y} F_{s k y}\left(T_{s k y}-T_{\text {surf }}\right)$

Eq. 9

The sky temperature $T_{s k y}$ is given by Swinbank [50], function of the air temperature as follow, assuming a clear sky:

$T_{\text {sky }}=0.0552 T_{\text {air }}^{1.5}$

Eq. 10

For a vertical wall, $F_{\text {grd }}$ and $F_{s k y}$ are equal to 0.5 . For the usual sky and surface temperatures, the coefficients $h_{r, s k y}$ and $h_{r, \text { grd }}$ range from $4.7 \mathrm{~W} / \mathrm{m}^{2} . \mathrm{K}$ to $5.7 \mathrm{~W} / \mathrm{m}^{2} . \mathrm{K}$ for buildings located in temperate regions.

The convective exchange with the external environment is generally calculated using a linear correlation function of the wind speed. The correlation in $\left(\mathrm{W} / \mathrm{m}^{2} \mathrm{~K}\right)$ used here is the one established by Sturrock [51]: 
$h_{\text {out }}=5.7 v+11.4($ Windward $)$

Eq. 11

$h_{\text {out }}=5.7 v($ Leeward $)$

where $v$ is the wind velocity $(\mathrm{m} / \mathrm{s})$

The heat balance on the internal surface is given by:

$\rho c_{p} \frac{\Delta x}{2} \frac{\partial T}{\partial t}=\emptyset_{\text {cond }}(t)+\emptyset_{\mathrm{LW,in}}(t)+\emptyset_{\text {conv }, \text { in }}(t)+\emptyset_{\text {sol }}(t)$

Eq. 12

Conduction flux through the wall $\left(\mathrm{W} / \mathrm{m}^{2}\right)$ is given as:

$\emptyset_{\text {cond }}(t)=\frac{k}{\Delta x}\left(T_{s-\Delta x}-T_{\text {surf }}\right)$

Eq. 13

The transmitted solar radiation flux absorbed at the internal wall surface reads:

$\emptyset_{\text {sol }}(t)=\alpha Q_{\text {sol-trans }}$

Eq. 14

where $\emptyset_{\mathrm{LW}, \text { in }}(t)$ and $\emptyset_{\text {conv,in }}(t)$ are the net longwave radiant exchange flux between zone surfaces $\left(\mathrm{W} / \mathrm{m}^{2}\right)$ and the convective heat flux with the indoor air.

The net longwave radiant exchange flux between zone surfaces is given by

$\emptyset_{L W, \text { in }}=\mathrm{h}_{\mathrm{is}}\left(\mathrm{T}_{\mathrm{in}}-\mathrm{T}_{\text {surf }}\right)$

Eq. 15

where $h_{i s}$ is the internal longwave radiative exchange coefficient, for standard building temperatures it varies very little around the value $5 \mathrm{~W} / \mathrm{m}^{2} . \mathrm{K}$

The internal convection coefficient used to evaluate the convection heat transfer for the TIMPCM wall with the interior is the one developed by Alamdari for vertical surfaces [38]:

$h_{\text {in }}=\left\{\left[1.5\left(\frac{|\Delta T|}{H}\right)^{1 / 4}\right]^{6}+\left[1.23(|\Delta T|)^{1 / 3}\right]^{6}\right\}^{1 / 6}$

Eq. 16

where $\Delta T$ is the temperature difference between the internal wall surface and the indoor air, and $\mathrm{H}$ is the height of the vertical surface.

A one-dimensional implicit finite volume method established by Patankar 1980 [52] is used to estimate the heat transfer mechanism through the TIM-PCM wall. The computational domain is divided into control volumes, the discretized equation over a typical control volume being written as follow:

$a_{P} T_{P}^{t+\Delta t}=a_{W} T_{W}^{t+\Delta t}+a_{E} T_{E}^{t+\Delta t}+b$

Eq. 17

where,

$a_{W}=k_{w} \frac{\Delta y}{(\Delta x)_{w}}, a_{E}=k_{e} \frac{\Delta y}{(\Delta x)_{e}}$

Eq. 18 
$a_{P}=a_{W}+a_{E}+a_{P}^{t}$

$a_{P}^{t}=\frac{\rho C p \Delta x}{\Delta t}$

$b=a_{P}^{t} T_{P}^{t}+\emptyset_{\text {sol }}$

The superscript $t$ indicates the values at the previous time step, $t+\Delta t$ indicates the values at the current time step. $k_{w}$ and $k_{e}$ are the thermal conductivities calculated at the interface.

A system of linear equations is formed from the discretized equations and can be written in a matrix form as:

$A * T=B$

Eq. 19

where $A$ is the matrix of coefficients (tri-diagonal sparse matrix), $T$ is the vector of unknown temperatures and $\mathrm{B}$ is the vector of known terms including the values at the previous time step. The current temperature values $T_{P}^{t+\Delta t}$ are obtained from the previously solved time step temperatures values $T_{P}^{t}$. The system is solved using a direct non-iterative method, the Gaussian elimination algorithm, which produces the solution without explicitly forming the inverse. This function is built in MATLAB.

The model of the heat transfer through the TIM-PCM wall is then linked to TRNSYS via Type 155, whose function is to enable the use of MATLAB program in TRNSYS. This link enables to simulate the thermal performance of the test cell. The MATLAB-TRSNYS model is then validated using experimental results of a full-sized test cell located at Sophia Antipolis within the center for Processes, Renewable Energies and Energy Systems (PERSEE) of Mines Paris Tech graduate school [32]. A good agreement is obtained between the simulated and the experimentally measured internal surface temperature of the TIM-PCM wall and the indoor air temperature for seven consecutive days in summer and winter. Table 10 shows the root mean square error $R M S E=\sqrt{\frac{1}{n} \sum_{i=1}^{n}\left(s_{i}-e_{i}\right)^{2}}$ and the percentage of root mean square error $P R M S E=$ $\sqrt{\frac{1}{n} \sum_{i=1}^{n}\left(\frac{s_{i}-e_{i}}{e_{i}}\right)^{2}}$ (where ei and si are the experimental and the simulated values respectively) for the hourly profile of the surface and indoor temperature in summer and winter season. The experimental surface temperature is an average of nine internal surface temperatures measured away from thermal bridges, while the experimental room temperature is an average of three air temperatures measured in the room. The simulated indoor temperature is calculated as an average temperature using the zonal model of TRNSYS. 
The validated numerical model allows to completely investigate the abilities and the drawbacks of the novel TIM-PCM wall under different conditions. More details on the numerical model and its validation can be found in [41].

Table 10: RMSE and PRMSE for the hourly profile of the surface and indoor temperature in summer and winter season

\begin{tabular}{llll}
\hline \multicolumn{1}{c}{ Season } & \multicolumn{1}{c}{ Physical quantity } & RMSE & PRMSE \\
\hline \multirow{2}{*}{ Winter } & Surface temperature & $1.43 \square \mathrm{C}$ & $6.99 \%$ \\
& Indoor air temperature & $0.76 \square \mathrm{C}$ & $4.05 \%$ \\
\hline \multirow{2}{*}{ Summer } & Surface temperature & $1.13 \square \mathrm{C}$ & $3.28 \%$ \\
& Indoor air temperature & $0.57 \square \mathrm{C}$ & $1.87 \%$ \\
\hline
\end{tabular}

\section{Energy Performance Analysis}

In this section, the results of the annual heating and cooling loads are presented for (1) an office with an opaque wall at the south orientation, (2) conventional office equipped with double glazing with different areas on the south wall, and (3) an office equipped with TIM-PCM wall with different dimensions (shown in Table 6) at the south orientation. The energy savings due to the use of the TIM-PCM wall are evaluated compared to the two cases: office with opaque wall and office with of double-glazing on the south wall.

Figure 3 and Table 11 show the annual heating loads in $\mathrm{kWh} / \mathrm{m}^{2}$ (floor area)/year in each climate, for different surface areas of the double-glazed window and the TIM-PCM wall (from $0 \mathrm{~m}^{2}$ (opaque wall) to $7.532 \mathrm{~m}^{2}$ ). The results show that, in all climates, the use of TIM-PCM wall at the south orientation instead of an opaque wall is very effective. In fact, the heating loads decrease with the increase of the area of the TIM-PCM wall (blue curve). This is due to the transmission of solar heat gains to the indoor environment (transmission of $90 \%$ when the PCM is liquid), the storage of the heat during the day and releasing it during the night (when the PCM works perfectly assuring diurnal cycling) and the superinsulation silica aerogel that prohibits the heat losses.

The first point on the curve (value at $0 \mathrm{~m}^{2}$ ) designates the heating loads of the office with an opaque wall at the south orientation of $U$ value $0.416 \mathrm{~W} / \mathrm{m}^{2} \mathrm{~K}$. The integration of TIM-PCM wall of area $7.53 \mathrm{~m}^{2}$ in the south wall instead of the opaque wall reduces the annual heating loads by $36.52 \%$ (from $228.54 \mathrm{kWh} / \mathrm{m}^{2} /$ year to $145.07 \mathrm{kWh} / \mathrm{m}^{2} /$ year) in Barentsburg (ET), by $38.90 \%$ 
(from $182.35 \mathrm{kWh} / \mathrm{m}^{2} /$ year to $111.44 \mathrm{kWh} / \mathrm{m}^{2} /$ year) in Kiruna (Dfc), by $51.69 \%$ (from 144.07 $\mathrm{kWh} / \mathrm{m}^{2} /$ year to $69.60 \mathrm{kWh} / \mathrm{m}^{2} /$ year) in Dras (Dsb), by $54.12 \%$ (from $96.53 \mathrm{kWh} / \mathrm{m}^{2} /$ year to $44.29 \mathrm{kWh} / \mathrm{m}^{2} /$ year) in Toronto (Dfa), by $62.24 \%$ (from $61.54 \mathrm{kWh} / \mathrm{m}^{2} /$ year to 23.24 $\mathrm{kWh} / \mathrm{m}^{2} /$ year) in Paris (Cfb) and by $90.04 \%$ (from $24.49 \mathrm{kWh} / \mathrm{m}^{2} /$ year to $2.44 \mathrm{kWh} / \mathrm{m}^{2} /$ year) in Sacramento ( Csa). This means that when the climate gets warmer, the percentage of heating savings increase, and the passive solar wall can provide heating needs to the building.

Concerning the conventional office equipped with double glazing, although the insulation performance of the double glazing ( $\mathrm{U}$ value $0.86 \mathrm{~W} / \mathrm{m}^{2} \mathrm{~K}$ ) is inferior to that of the opaque external wall $\left(0.416 \mathrm{~W} / \mathrm{m}^{2} \mathrm{~K}\right)$, the heating loads decrease with the increase of the area of the double-glazing (orange curve). This reduction is due mainly to the solar heat gains provided by the transparent double glazing. However, the continuous reduction in heating loads is not always true especially in colder climates (Barentsburg (ET) and Kiruna (Dfc)), where the increase of the double-glazing area is not beneficial exceeding a certain area. The heating loads started to increase again using a double glazing of an area larger than $5.27 \mathrm{~m}^{2}$. In this case, the impact of the $\mathrm{U}$ value reduction of the wall is more influential than the effect of solar heat gains.

The percentage of heating loads reduction due to the increase of glazing area depends mainly on the climate and the amount of the incident solar radiation, and this reduction is found less significant than that when the TIM-PCM wall is used. The integration of double glazing of area $7.53 \mathrm{~m}^{2}$ in the south wall reduces the annual heating loads by $26.59 \%$ (from $144.07 \mathrm{kWh} / \mathrm{m}^{2} /$ year to $105.76 \mathrm{kWh} / \mathrm{m}^{2} /$ year) in Dras (Dsb), by $28.29 \%$ (from $96.53 \mathrm{kWh} / \mathrm{m}^{2} /$ year to 69.22 $\mathrm{kWh} / \mathrm{m}^{2} /$ year) in Toronto (Dfa), by $32.43 \%$ (from $61.54 \mathrm{kWh} / \mathrm{m}^{2} /$ year to $41.58 \mathrm{kWh} / \mathrm{m}^{2} /$ year) in Paris (Cfb) and by $79.95 \%$ (from $24.49 \mathrm{kWh} / \mathrm{m}^{2} /$ year to $4.91 \mathrm{kWh} / \mathrm{m}^{2} /$ year) in Sacramento ( Csa). Also, when the climate gets warmer, the percentage of heating reduction increase. 


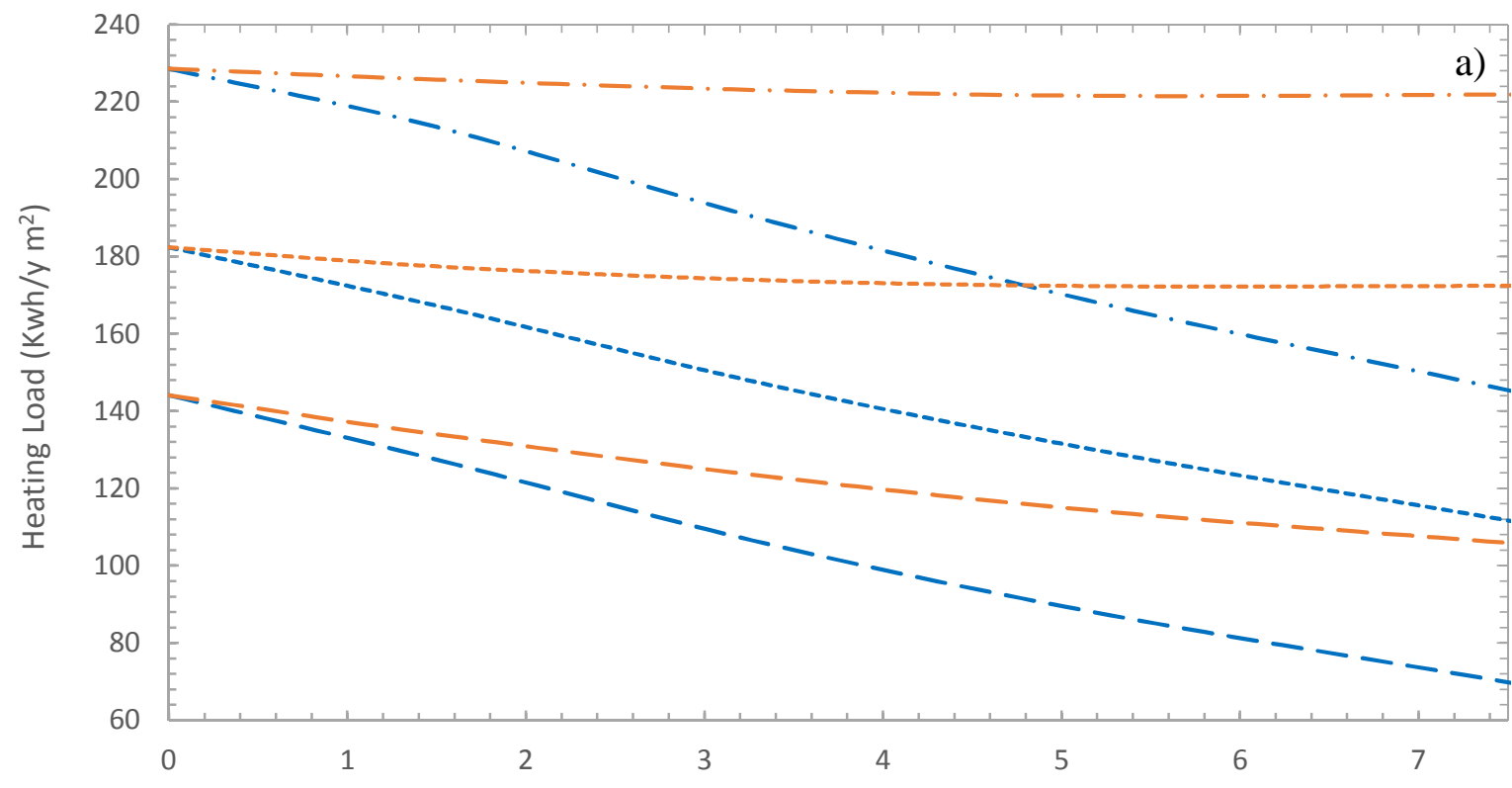

TIM-PCM wall surface or double glazing surface $\left(\mathrm{m}^{2}\right)$ at the south orientation

$$
\begin{array}{lll}
- \text { Dras(Dsb)_PCM } & ---- \text { Kiruna(Df)_PCM } & -\cdot-\text { Barentsburg(ET)_PCM } \\
- \text { - Dras(Dsb)_conv } & ----- \text { Kirina(Dfc)_Conv } & -\cdot-\text { Barentsburg(ET)_conv }
\end{array}
$$

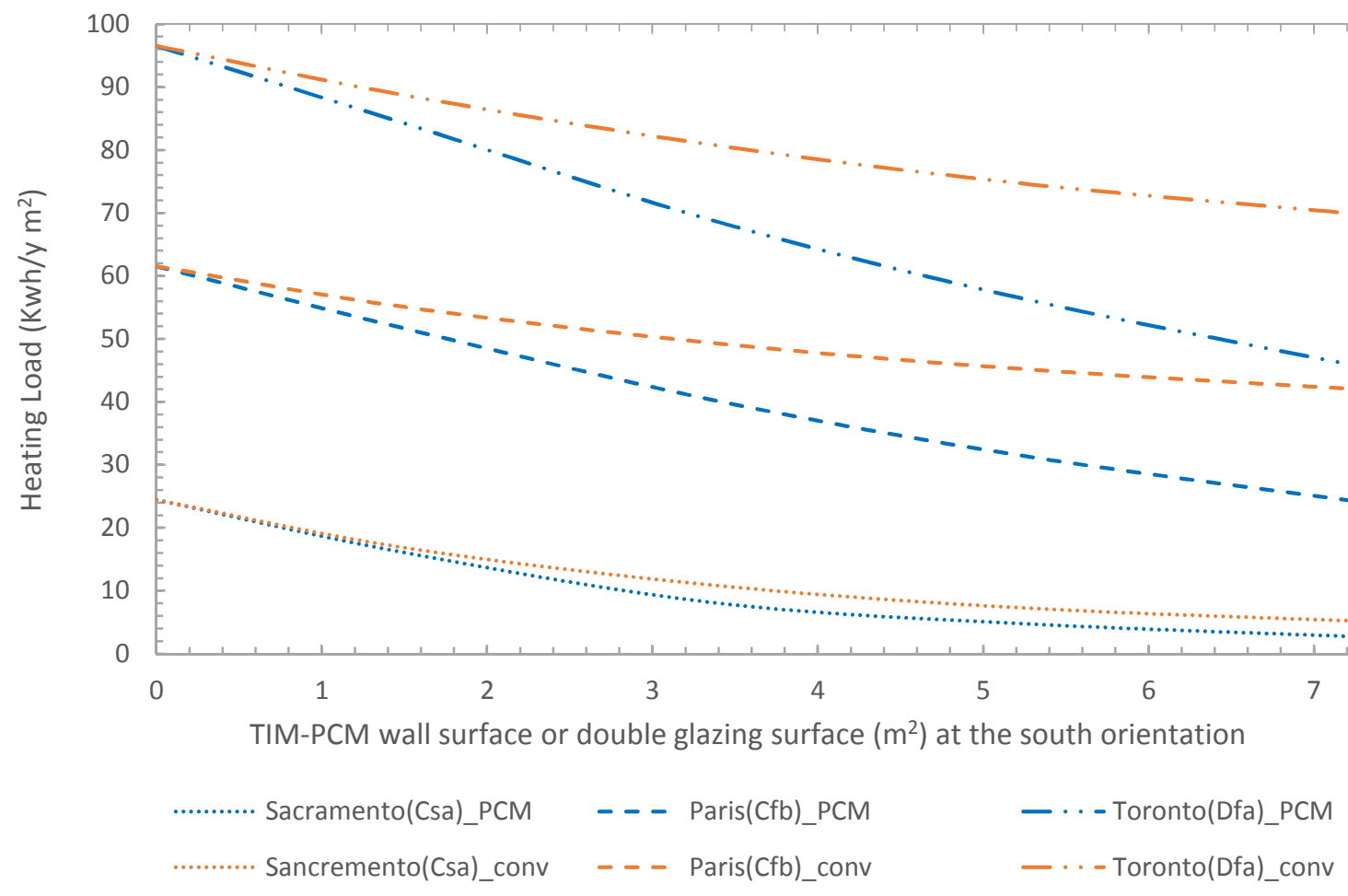

Figure 3: Annual heating load for (a) Dsb, Dfc, ET climates and (b) Csa, Cfb, Dfa climates function of the TIM-PCM wall or the double glazing $\left(\mathrm{U}\right.$ value $\left.=0.86 \mathrm{~W} / \mathrm{m}^{2} \mathrm{~K}\right)$ area. 
Table 11: Annual heating loads $\left(\mathrm{kWh} / \mathrm{m}^{2} /\right.$ year) for each city (climate) for an office equipped with double glazing and PCM enhanced office for different double glazing or TIM-PCM wall surfaces

\begin{tabular}{|c|c|c|c|c|c|c|c|c|c|}
\hline \multicolumn{10}{|c|}{ Annual heating loads (kWh/m²/year) } \\
\hline & $\begin{array}{l}\text { Office with } \\
\text { opaque } \\
\text { south wall }\end{array}$ & \multicolumn{4}{|c|}{$\begin{array}{c}\text { Office with double glazing }(\mathrm{U} \\
\left.\text { value }=0.86 \mathrm{~W} / \mathrm{m}^{2} \mathrm{~K}\right) \text { on the south } \\
\text { wall }\end{array}$} & \multicolumn{4}{|c|}{$\begin{array}{l}\text { Office with TIM-PCM wall at the } \\
\text { south orientation }\end{array}$} \\
\hline $\begin{array}{l}\text { Area of double } \\
\text { glazing or TIM- } \\
\text { PCM wall }\left(\mathrm{m}^{2}\right)\end{array}$ & 0 & 1.51 & 3.39 & 5.27 & 7.53 & 1.51 & 3.39 & 5.27 & 7.53 \\
\hline Barentsburg (ET) & 228.54 & 225.71 & 222.94 & 221.52 & 221.87 & 213.41 & 188.84 & 167.31 & 145.07 \\
\hline Kiruna (Dfc) & 182.35 & 177.39 & 173.77 & 172.28 & 172.38 & 167.16 & 146.47 & 129.23 & 111.44 \\
\hline Dras (Dsb) & 144.07 & 133.92 & 122.86 & 113.88 & 105.76 & 127.34 & 105.22 & 87.18 & 69.60 \\
\hline Toronto (Dfa) & 96.53 & 88.67 & 80.72 & 74.58 & 69.22 & 84.18 & 68.63 & 56.21 & 44.29 \\
\hline Paris(Cfb) & 61.54 & 55.04 & 49.27 & 45.15 & 41.58 & 51.61 & 40.16 & 31.29 & 23.24 \\
\hline Sacramento (Csa) & 24.49 & 16.81 & 10.83 & 7.23 & 4.91 & 16.03 & 8.48 & 4.73 & 2.44 \\
\hline
\end{tabular}

Now, comparing the heating loads of the office with double glazing with those of the office with integrated TIM-PCM wall (comparing the orange curve with the blue curve at each area).

The energy performance of the office, in term of heating loads, can be significantly improved in all climates following the incorporation of the TIM-PCM wall instead of a conventional double glazing, especially for larger areas. This can be clearly shown in Figure 3 and Table 11, where the heating loads of PCM-enhanced office are always lower than those of the conventional office with double-glazing. For example, the integration of the TIM-PCM wall of $7.53 \mathrm{~m}^{2}$ instead of the double glazing of the same area decreases the heating loads from $221.87 \mathrm{kWh} / \mathrm{m}^{2} /$ year to 145.07 $\mathrm{kWh} / \mathrm{m}^{2} /$ year in Barenstburg (ET) and from $105.76 \mathrm{kWh} / \mathrm{m}^{2} /$ year to $69.60 \mathrm{kWh} / \mathrm{m}^{2} /$ year in Dras (Dsb). This is mainly due to the energy storage provided by the PCM and the superinsulation of the silica aerogel that prohibits the heat losses, especially at night.

The annual heating savings in $\mathrm{kWh} / \mathrm{m}^{2} /$ year and their associated percentages due to the integration of TIM-PCM wall instead of double glazing of different areas are shown in Table 12 and Figure 4. These heating savings always increase with the increase of the TIM-PCM wall area. For example, in Toronto, heating savings increase from 5.06\% using a TIM-PCM wall of area $1.51 \mathrm{~m}^{2}$ to $36.01 \%$ using a TIM-PCM wall of area $7.53 \mathrm{~m}^{2}$. In all climates, the maximum heating savings following the integration of the TIM-PCM wall instead of the double glazing are reached when the surface area of the TIM-PCM wall is $7.53 \mathrm{~m}^{2}$, and are found $34.62 \%$ (76.80 
$\mathrm{kWh} / \mathrm{m}^{2} /$ year) in Barentsburg, 35.35\% (60.94 $\mathrm{kWh} / \mathrm{m}^{2} /$ year) in Kiruna (Dfc), $34.18 \%(36.15$ $\mathrm{kWh} / \mathrm{m}^{2} /$ year) in Dras (Dsb), 36.01\% $\left(24.93 \mathrm{kWh} / \mathrm{m}^{2} /\right.$ year) in Toronto (Dfa), $44.11 \%$ (18.33 $\mathrm{kWh} / \mathrm{m}^{2} /$ year) in Paris (Cfb) and $50.32 \%\left(2.47 \mathrm{kWh} / \mathrm{m}^{2} /\right.$ year) in Sacramento (Csa). We note that, although the PCM works better in Dras, the heating savings in Barentsburg are found higher (Table 12). This can be explained by the fact the performance of the office with double glazing is better in Dras due to higher solar heat gains, while in Braentsburg the heating loads of the office with double glazing barely decrease with the increase of its area. In addition, the percentage of heating savings is found more significant for warmer climates Csa and $\mathrm{Cfb}$. The heating demand can be almost entirely met by the solar energy alone in Sacramento (Csa) using the TIM-PCM wall.

Table 12: Annual heating savings in ( $\left.\mathrm{kWh} / \mathrm{m}^{2} / \mathrm{year}\right)$ by using TIM-PCM wall instead of double-glazed window $\left(\mathrm{U}\right.$ value $\left.=0.86 \mathrm{~W} / \mathrm{m}^{2} \mathrm{~K}\right)$ at south orientation

\begin{tabular}{|l|c|c|c|c|c|c|c|c|}
\hline $\begin{array}{l}\text { Area of double } \\
\text { glazing or TIM-PCM } \\
\text { wall }\left(\mathrm{m}^{2}\right)\end{array}$ & \multicolumn{2}{|c|}{1.51} & \multicolumn{2}{c|}{3.39} & \multicolumn{2}{c|}{5.27} & \multicolumn{2}{c|}{7.53} \\
\hline Heating Savings & $\begin{array}{c}\Delta_{\mathrm{HL}} \\
\mathrm{kWh} / \mathrm{m}^{2}\end{array}$ & $\%$ & $\begin{array}{c}\Delta_{\mathrm{HL}} \\
\mathrm{kWh} / \mathrm{m}^{2}\end{array}$ & $\%$ & $\begin{array}{c}\Delta_{\mathrm{HL}} \\
\mathrm{kWh} / \mathrm{m}^{2}\end{array}$ & $\%$ & $\begin{array}{c}\Delta_{\mathrm{HL}} \\
\mathrm{kWh} / \mathrm{m}^{2}\end{array}$ & $\%$ \\
\hline Barentsburg (ET) & 12.30 & $5.45 \%$ & 34.09 & $15.29 \%$ & 54.21 & $24.47 \%$ & 76.80 & $34.62 \%$ \\
\hline Kiruna (Dfc) & 10.22 & $5.76 \%$ & 27.29 & $15.71 \%$ & 43.04 & $24.98 \%$ & 60.94 & $35.35 \%$ \\
\hline Dras (Dsb) & 6.58 & $4.91 \%$ & 17.64 & $14.36 \%$ & 26.70 & $23.44 \%$ & 36.15 & $34.18 \%$ \\
\hline Toronto (Dfa) & 4.48 & $0.1 \%$ & 12.08 & $14.97 \%$ & 18.37 & $24.64 \%$ & 24.93 & $36.01 \%$ \\
\hline Paris(Cfb) & 3.42 & $6.22 \%$ & 9.11 & $18.49 \%$ & 13.85 & $30.68 \%$ & 18.33 & $44.11 \%$ \\
\hline Sacramento (Csa) & 0.78 & $4.64 \%$ & 2.35 & $21.70 \%$ & 2.49 & $34.51 \%$ & 2.47 & $50.32 \%$ \\
\hline
\end{tabular}




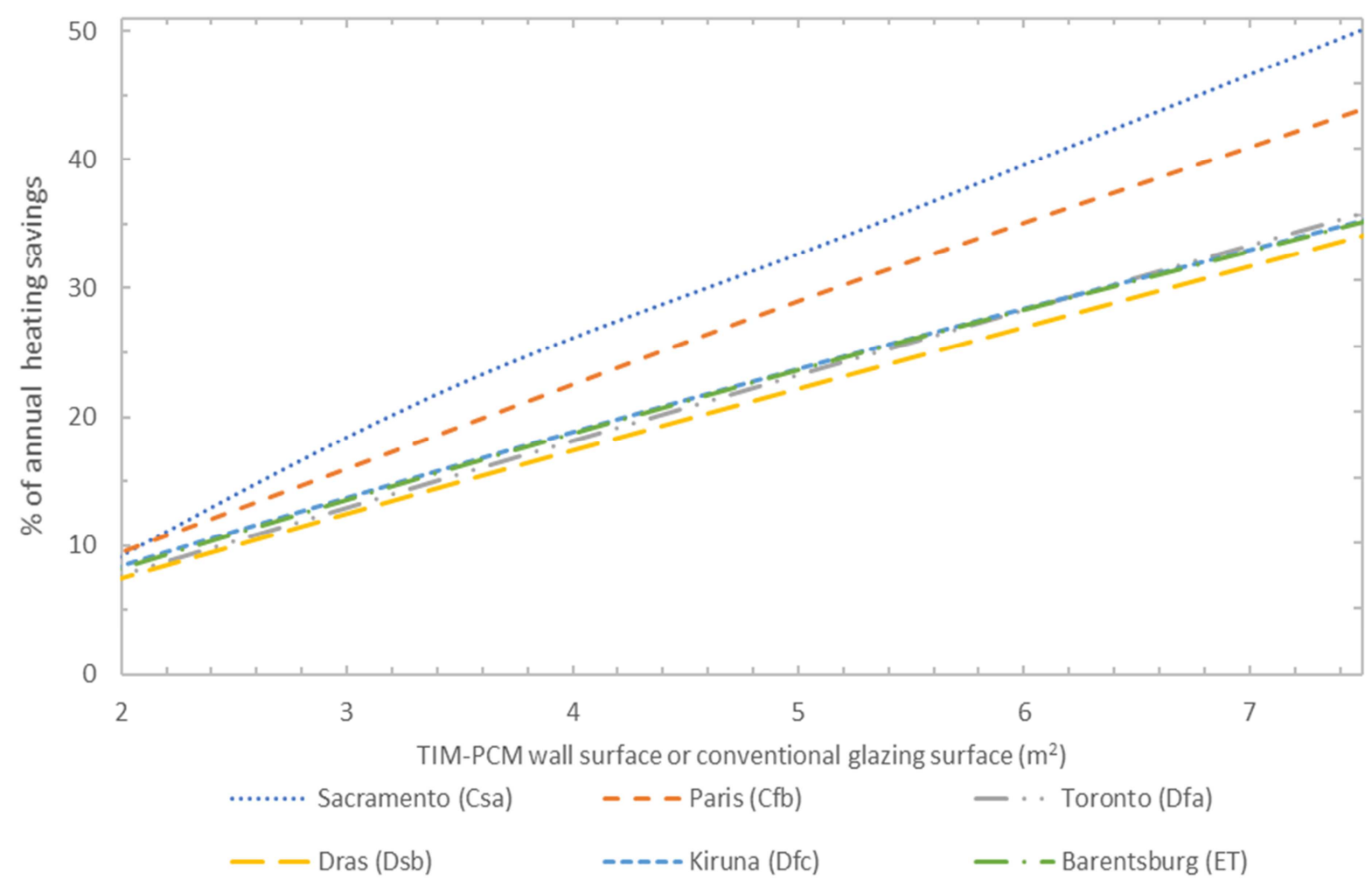

Figure 4: Percentage of annual heating savings with respect to conventional office with insulated doubleglazed window $\left(\mathrm{U}\right.$ value $\left.=0.86 \mathrm{~W} / \mathrm{m}^{2} \mathrm{~K}\right)$ at south orientation

Figure 5 and Table 13 show the annual cooling loads in $\mathrm{kWh} / \mathrm{m}^{2} /$ year for each climate for different surface areas of the TIM-PCM wall or the double-glazed window (from $0 \mathrm{~m}^{2}$ to $\left.7.532 \mathrm{~m}^{2}\right)$.

Table 13: Annual cooling loads $\left(\mathrm{kWh} / \mathrm{m}^{2} / \mathrm{year}\right)$ for each city (climate) for conventional office and PCM enhanced office for different surfaces

\begin{tabular}{|l|c|c|c|c|c|c|c|c|c|}
\hline \multicolumn{10}{|c|}{ Cooling loads (Kwh/m $/$ /year) } \\
\hline & $\begin{array}{l}\text { Office with } \\
\text { Opaque wall }\end{array}$ & \multicolumn{3}{|c|}{ Office with double glazing U value } & \multicolumn{3}{c|}{ Office with TIM-PCM wall } \\
\hline $\begin{array}{l}\text { Area of window or } \\
\text { TIM-PCM wall (m }{ }^{2} \text { ) }\end{array}$ & 0 & 1.51 & 3.39 & 5.27 & 7.53 & 1.51 & 3.39 & 5.27 & 7.53 \\
\hline Barentsburg (ET) & 0 & 0 & 0 & 0.034 & 0.58 & 0 & 0 & 0 & 0.17 \\
\hline Kiruna (Dfc) & 0 & 0 & 0 & 0.44 & 2.27 & 0 & 0 & 0.21 & 1.28 \\
\hline Dras (Dsb) & 0 & 0.18 & 1.21 & 3.20 & 6.93 & 0.22 & 1.34 & 3.13 & 6.53 \\
\hline Toronto (Dfa) & 0.82 & 3.45 & 7.14 & 11.86 & 19.08 & 3.24 & 6.51 & 10.40 & 15.82 \\
\hline Paris(Cfb) & 0 & 0.54 & 2.39 & 5.58 & 11.44 & 0.46 & 2.13 & 4.65 & 8.87 \\
\hline Sacramento (Csa) & 4.23 & 8.62 & 16.72 & 27.18 & 43.38 & 8.53 & 15.86 & 24.61 & 36.84 \\
\hline
\end{tabular}




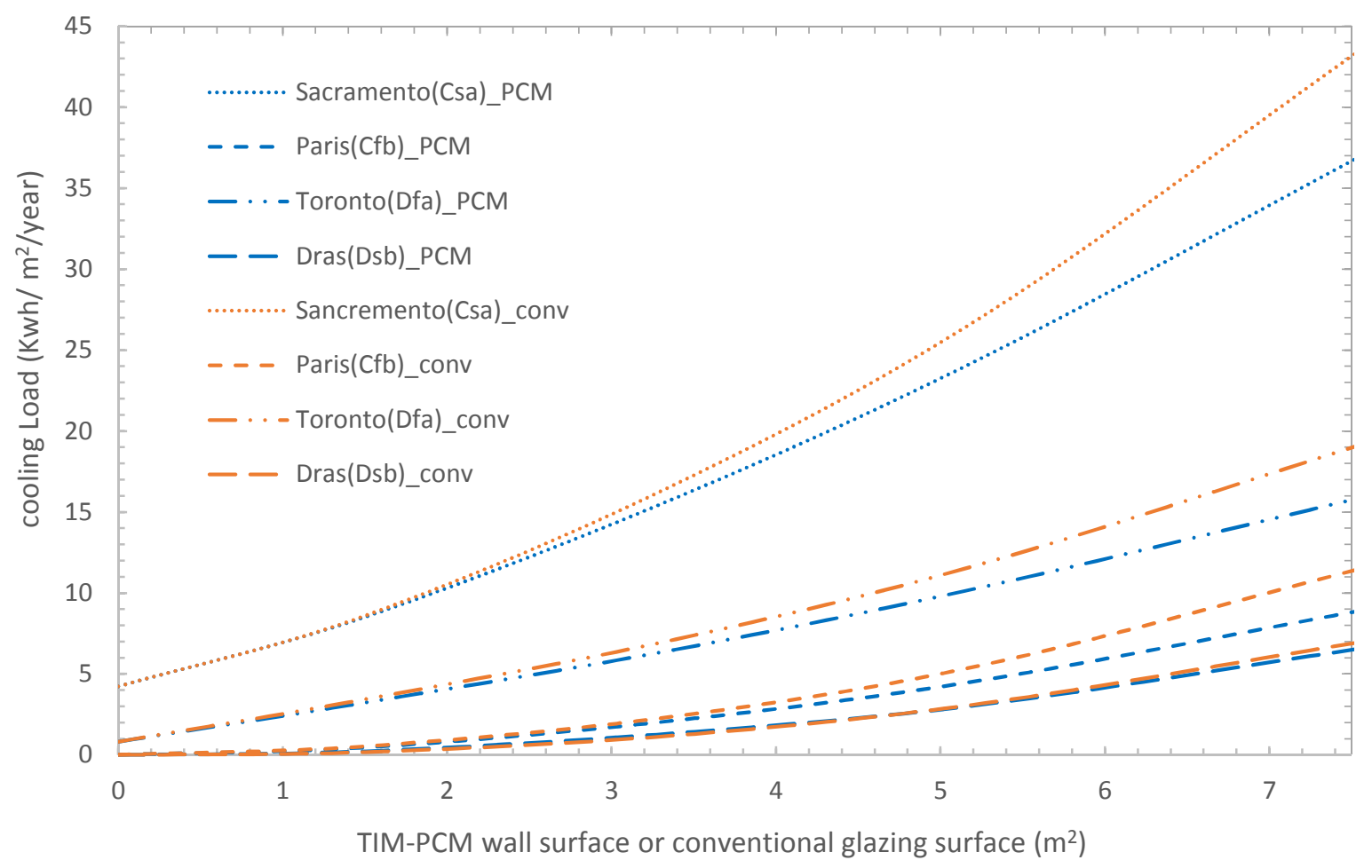

Figure 5: Annual cooling load for each city (climate) function of the TIM-PCM wall or the conventional glazing $\left(\mathrm{U}\right.$ value $\left.=0.86 \mathrm{~W} / \mathrm{m}^{2} \mathrm{~K}\right)$ surface

In polar climate and Continental subarctic climate, no cooling loads are found. In all other climates, the cooling loads increase for larger areas, this increase is more significant for the conventional office equipped with double glazing. For both cases, the increase of cooling loads in the hot summer season is due to higher solar heat gains. The maximum cooling savings following the integration of TIM-PCM wall instead of double glazing reach $17.07 \%\left(3.26 \mathrm{kWh} / \mathrm{m}^{2} / \mathrm{year}\right)$ in Toronto (Dfa), $22.47 \%\left(2.57 \mathrm{kWh} / \mathrm{m}^{2} /\right.$ year) in Paris $(\mathrm{Cfb})$ and $15 \%\left(6.53 \mathrm{kWh} / \mathrm{m}^{2} /\right.$ year $)$ in Sacramento (Csa) when the surface area of the TIM-PCM wall is $7.53 \mathrm{~m}^{2}$. These results show that in a region with mild to hot summer, the TIM-PCM wall is a better choice than a conventional double-glazed window to maintain a cool indoor temperature. In Dras (Dsb) the cooling savings are not significant as shown in Table 14 and no cooling savings are found when the area of the TIM-PCM wall is $1.51 \mathrm{~m}^{2}$ and $3.39 \mathrm{~m}^{2}$. However, the use of shading devices in summer can decrease the cooling loads. The use of Venetian blinds with rotatable slats of 45 degrees, allowing daylighting, reduce the cooling loads by $32 \%$ in Sacramento (Csa). The use Overhang of $1 \mathrm{~m}$ projection combined with the Venetian blinds can reduce this cooling loads by 
$38 \%$. In Toronto (Dfa) the use of same blinds decreases the cooling loads by about $64 \%$. This can be explained by the fact that the cooling loads in Sacramento (Csa) are not due only to the transmitted solar radiation but also to the high outdoor ambient temperature, reaching $40{ }^{\circ} \mathrm{C}$, while in Toronto (Dfa) cooling loads are mainly due to the high solar radiation transmitted to the interior with a maximum outdoor temperature of $31^{\circ} \mathrm{C}$. The use of Venetian blinds in Paris $(\mathrm{Cfb})$ and Dras (Dsb) reduces the cooling loads by about $71 \%$ and $78 \%$ respectively.

Table 14: Annual cooling savings in (KWh/m2/year) by using TIM-PCM wall instead of double-glazed window $(\mathrm{U}$ value $=0.86 \mathrm{~W} / \mathrm{m} 2 \mathrm{~K})$ at south orientation

\begin{tabular}{|l|c|c|c|c|c|c|c|c|}
\hline $\begin{array}{l}\text { Area of window or } \\
\text { TIM-PCM wall }\left(\mathrm{m}^{2}\right)\end{array}$ & \multicolumn{2}{|c|}{1.51} & \multicolumn{2}{c|}{3.39} & \multicolumn{2}{c|}{5.27} & \multicolumn{2}{c|}{7.53} \\
\hline Heating Savings & $\begin{array}{c}\Delta_{\mathrm{CL}} \\
\mathrm{Kwh} / \mathrm{m}^{2}\end{array}$ & $\%$ & $\begin{array}{c}\Delta_{\mathrm{CL}} \\
\mathrm{Kwh} / \mathrm{m}^{2}\end{array}$ & $\%$ & $\begin{array}{c}\Delta_{\mathrm{CL}} \\
\mathrm{Kwh} / \mathrm{m}^{2}\end{array}$ & $\%$ & $\begin{array}{c}\Delta_{\mathrm{CL}} \\
\mathrm{Kwh} / \mathrm{m}^{2}\end{array}$ & $\%$ \\
\hline Barentsburg (ET) & 0 & $0 \%$ & 0 & $0 \%$ & 0.034 & - & 0.41 & - \\
\hline Kiruna (Dfc) & 0 & $0 \%$ & 0 & $0 \%$ & 0.22 & - & 0.99 & $-\%$ \\
\hline Dras (Dsb) & -0.05 & $-28.3 \%$ & -0.14 & $-11.5 \%$ & 0.07 & $2.14 \%$ & 0.40 & $5.77 \%$ \\
\hline Toronto (Dfa) & 0.20 & $5.91 \%$ & 0.63 & $8.79 \%$ & 1.46 & $12.31 \%$ & 3.26 & $17.07 \%$ \\
\hline Paris(Cfb) & 0.07 & $13.91 \%$ & 0.26 & $10.83 \%$ & 0.94 & $16.77 \%$ & 2.57 & $22.47 \%$ \\
\hline Sacramento (Csa) & 0.08 & $0.94 \%$ & 0.85 & $5.09 \%$ & 2.57 & $9.45 \%$ & 6.53 & $15 \%$ \\
\hline
\end{tabular}

Figure 6 shows the annual total energy loads for three different climates (Csa, Cfb, Dfa). Concerning other climates, the total energy loads are very close to the heating loads due to the respectively insignificant cooling loads.

In all considered climates, the total energy loads of the conventional office with double glazing and the PCM-enhanced office decrease with the increase of the area except in Sacramento (Csa) (because of high cooling loads due to high solar gains). But still, the TIM-PCM wall performs better than the double glazing. The use TIM-PCM wall is more efficient than the use of a conventional insulated double-glazed window in terms of total energy loads in all considered climates, especially for larger areas where maximum total energy savings are reached. The total energy savings in $\mathrm{kWh} / \mathrm{m}^{2} / \mathrm{year}$ due to the integration of TIM-PCM wall instead of double glazing on the south orientation are shown in Figure 7-a.

On the other hand, comparing the results of total energy savings of the office with opaque wall at the south orientation with those of the office with integrated TIM-PCM wall shows that increasing the TIM-PCM wall area increases the total energy savings in all studied climates 
except in Mediterranean climate (Csa), having a hot summer, where the maximum energy savings are reached at an area of $2.61 \mathrm{~m}^{2}$ (Figure 7-b). Above this area no savings can be achieved because the cooling loads increases significantly due to higher solar gains which increases the total energy loads. The total energy savings following the integration of TIM-PCM wall instead of an opaque wall in $\mathrm{kWh} / \mathrm{m}^{2} /$ year are shown in Figure $7-\mathrm{b}$.

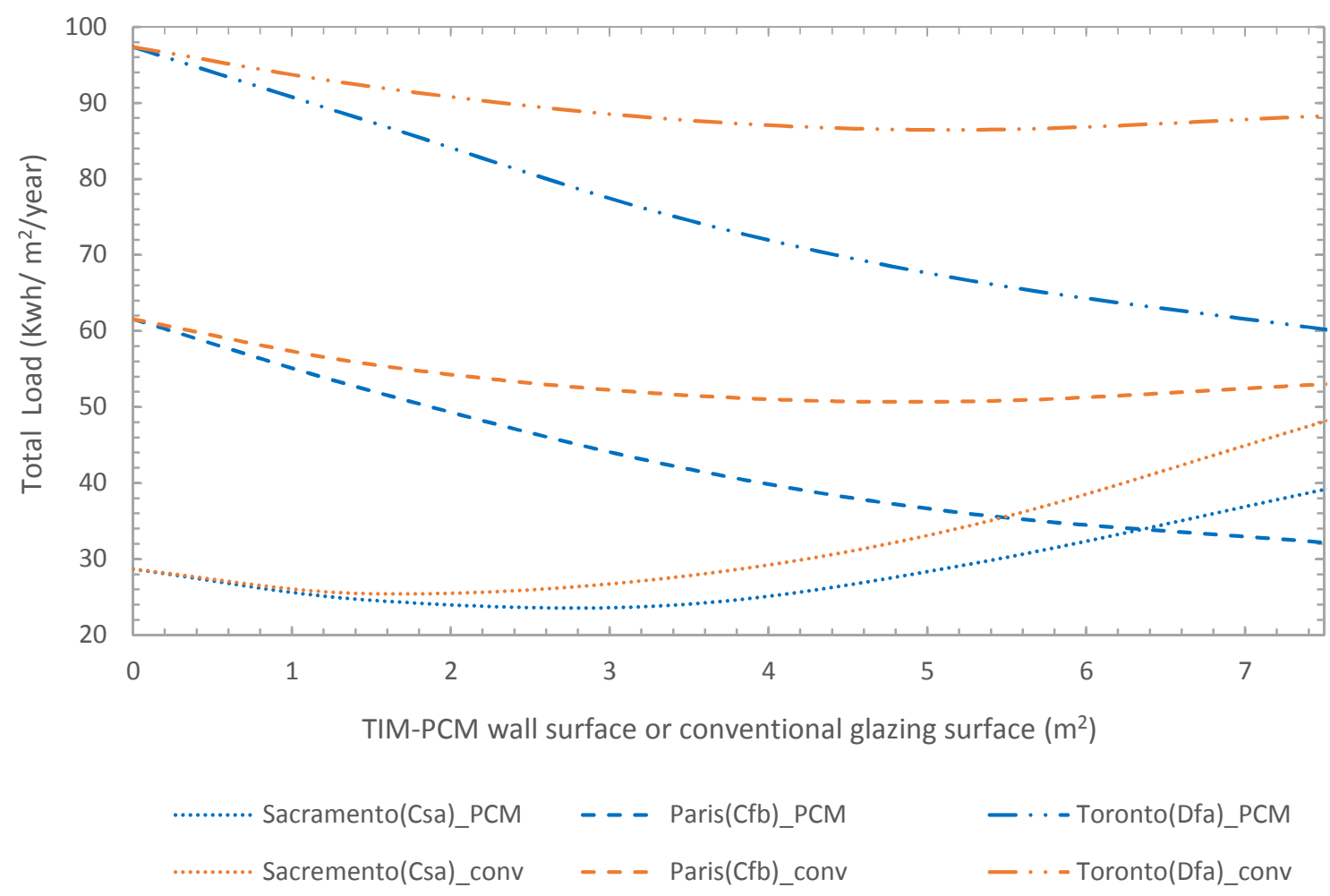

Figure 6: Annual total load for three different climates function of the TIM-PCM wall or the conventional glazing $\left(\mathrm{U}\right.$ value $\left.=0.86 \mathrm{~W} / \mathrm{m}^{2} \mathrm{~K}\right)$ surface 

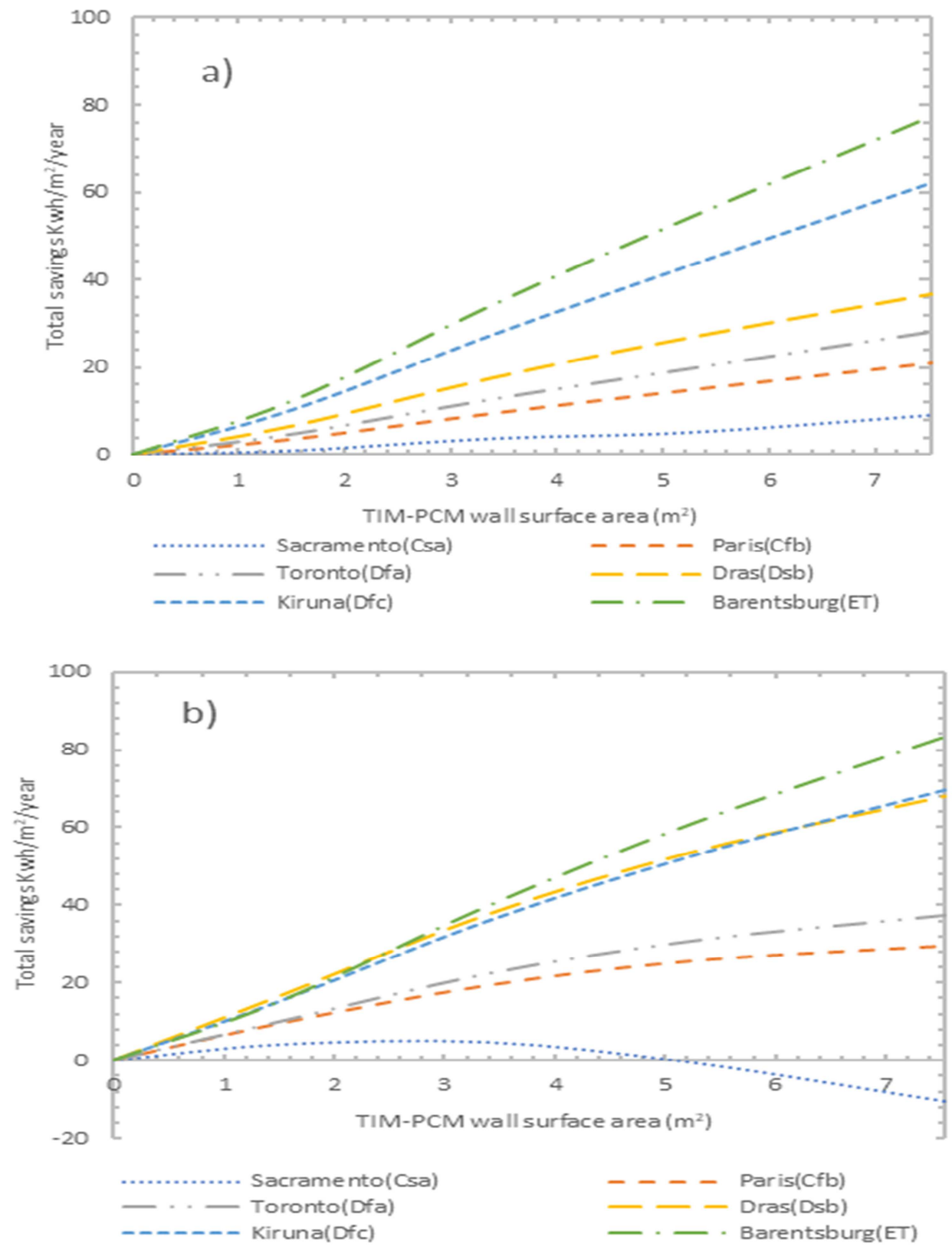

Figure 7: Annual total savings for each city (climate) as function of TIM-PCM wall surface with respect to a) conventional office with insulated double-glazed window and b) office with opaque wall at the south orientation 


\section{Economic Analysis}

In addition to the investigation of the thermal and energy performance of the innovative TIMPCM wall, an economic assessment is carried out for the applicability of this wall in buildings. In previous studies, economic analyses related to the application of PCM in buildings were conducted based on a life-cycle cost analysis [23] [24] or based on a payback period evaluation [28] [30]. The economic study in this work is based on the same concept of previous studies [23][24][53], and both life cycle cost analysis and payback period evaluation are conducted. Noting that the environmental impact of PCM incorporated in building envelopes can be assessed by employing a Life Cycle Assessment (LCA) approach. Many studies [54] have found that the PCM is more environmental friendly compared to other conventional thermal insulating material. The life-cycle cost analysis involves the analysis of the costs of a system or a component over its entire lifetime. The optimum TIM-PCM wall area (otherwise PCM volume) corresponds to the value that provides a minimum total life-cycle cost. It depends mainly on the yearly heating and cooling loads, the costs of natural gas and electricity, the building lifetime, and the discount rate. The life cycle cost or LCC is defined by:

$L C C=I C+\mathrm{PWF} . E C$

Eq. 19

where $I C$ is the initial cost for implementing the considered wall (materials prices + installation + labor cost), $E C$ is the annual energy cost required to maintain indoor comfort within the office building for the selected design and operating features and $P W F$ is the present worth factor. The heating and cooling costs over the lifetime of the building are evaluated as:

$$
\begin{array}{ll}
E C_{h}=\frac{Q_{h}}{\eta} * c_{n g} & \text { Eq. 20 } \\
E C_{c}=\frac{Q_{c}}{C O P} * c_{e} & \text { Eq. 21 }
\end{array}
$$

where $E C_{h}$ and $E C_{c}$ are the heating and cooling costs over the lifetime of the building. $Q_{h}, Q_{c}$, $c_{n g}, c_{e}, \eta, C O P$ respectively stand for the annual heating load, annual cooling load, natural gas cost, cost of electricity, heating system efficiency and the coefficient of performance of the cooling system.

The present worth factor PWF converts future recurrent expenses to present costs regarding the economic outlook of the country and depends on the discount rate $r$ and on the lifetime $N$. The 
discount rate is the general interest rate of the country. Therefore, when evaluating the present value of a certain investment via $P W F$, the discount rate should be considered in the formulation. The PWF is given by [55]:

$P W F=\frac{1-(1+r)^{-N}}{r}$

Eq. 22

In addition, the simple payback period PP for the TIM-PCM wall integrated into the building envelope is calculated by dividing the total initial cost by the energy savings cost [53]:

$P P=I C / E S C$

Eq. 23

where $P P, I C$, and $E S C$ are respectively the payback period, the initial cost and the cost of energy savings including annual lighting savings cost in cities where its value is influential.

The initial investment cost was calculated considering only the material and installation costs (including labor cost) related to the building envelope (TIM-PCM wall). The installation cost of the HVAC systems and other design costs were not considered since their value was assumed to be the same for all the cases in the same location. For the same reason, only the energy costs were considered as annual costs. To evaluate the final value, the lifetime of the building is assumed to be 30 years.

In each country different electricity costs, natural gas prices, and different labor costs are considered. In most projects, labor costs represent approximately 25 to $35 \%$ of the total project costs [56]. The labor cost is estimated in each country between these two values (lower income countries have lower labor cost). Although the prices change according to the location, the material costs were assumed to be unvaried but later multiplied by the labor cost. The heating system is a natural gas boiler with an efficiency of $90 \%$.

The cooling load is covered using a commercial electrical vapor-compression heat pump of variable COP. A characteristic polynomial equation form could be obtained using the manufacturer's data, where the compressor refrigeration capacity $\left(Q_{\text {evap }}\right)$ and the actual compressor power consumption ( $\left.P_{\text {compressor }}\right)$ may be expressed as a function of evaporating $\left(\mathrm{T}_{\text {evap }}\right)$ and condensing $\left(\mathrm{T}_{\text {cond }}\right)$ temperatures [57] [58] [59] :

$Q_{\text {evap }}=a_{0}+a_{1} T_{\text {evap }}+a_{2} T_{\text {cond }}+a_{3} T_{\text {evap }}^{2}+a_{4} T_{\text {evap }} T_{\text {cond }}+a_{5} T_{\text {cond }}^{2}+a_{6} T_{\text {evap }}^{3}+$ $a_{7} T_{\text {evap }}^{2} T_{\text {cond }}+a_{8} T_{\text {evap }} T_{\text {cond }}^{2}+a_{9} T_{\text {cond }}^{3}$ 
$P_{\text {compressor }}=b_{0}+b_{1} T_{\text {evap }}+b_{2} T_{\text {cond }}+b_{3} T_{\text {evap }}^{2}+b_{4} T_{\text {evap }} T_{\text {cond }}+b_{5} T_{\text {cond }}^{2}+$

$b_{6} T_{\text {evap }}^{3}+b_{7} T_{\text {evap }}^{2} T_{\text {cond }}+b_{8} T_{\text {evap }} T_{\text {cond }}^{2}+b_{9} T_{\text {cond }}^{3}$

Subsequently, the coefficient of performance is calculated as follow

COP $=\frac{Q_{\text {evap }}}{P_{\text {compressor }}}$

Eq. 26

The COP is calculated at each time-step for all cases in each climate and the values are found to be between 2 and 4 .

The cost of electricity and the natural gas, the discount rate and the PWF are found for each country as summarized in Table 15 . The prices represent the final total cost including tax and grid costs.

Table 15: Cost of electricity, natural gas price and discount rate for each country

\begin{tabular}{lcccc}
\hline \multicolumn{1}{c}{ City } & $\begin{array}{c}\text { Electricity price } \\
\text { \$ per } \mathbf{k W h}[60],[61]\end{array}$ & $\begin{array}{c}\text { Natural Gas price } \\
\mathbf{\$} \text { per kWh [62]-[64] }\end{array}$ & $\begin{array}{c}\text { Discount rate \% } \\
\text { [65], [66] }\end{array}$ & PWF \\
\hline Barents burg (Norway) & 0.1786 & 0.078 & 0.5 & 27.79 \\
Kiruna (Sweden) & 0.22 & 0.121 & -0.5 & 32.45 \\
Dras (India) & 0.08 & 0.02 & 6 & 13.76 \\
Toronto (Canada) & 0.16 & 0.0113 & 1 & 25.81 \\
Paris (France) & 0.2 & 0.064 & 0.05 & 29.76 \\
Sacramento (USA) & 0.21 & 0.011 & 1.25 & 24.88 \\
\hline
\end{tabular}

Table 16: Prices of materials

\begin{tabular}{lc}
\hline \multicolumn{1}{c}{ Materials } & Prices \\
\hline Concrete & $100 \$ / \mathrm{m}^{3}[67]$ \\
Plasterboard & $15 \$$ to $20 \$ / \mathrm{m}^{2}[68]$ \\
Glass wool & $60-100 \$ / \mathrm{m}^{3} \cdot[69]$ \\
Fatty acid PCM product & $3.23 \$ / \mathrm{kg}[70]$ \\
Silica aerogel & $550 \$ \mathrm{~m}^{3}[66]$ \\
Single clear glazing & $29.97 \$ / \mathrm{m}^{2}[54]$ \\
Insulated double glazing & $102 \$ / \mathrm{m}^{2}[54]$ \\
\hline
\end{tabular}

The prices of the used materials are summarized in Table 16. The price of PCM varies widely, according to their type, melting temperature and purity [25]. Unfortunately, it is impossible to take these factors into account to accurately estimate the price of PCM. Cascone et al. [71] estimated the price of PCM at about $40 € / \mathrm{m}^{2}$ for each cm of thickness. An additional 20\% was considered for macroencapsulation [25]. The total estimated price of PCM was hence $48 € / \mathrm{m}^{2}$ $/ \mathrm{cm}$, plus $4.36 € / \mathrm{m}^{2}$ for installation [72]. Baniassadi et al.[23] considered that finding an exact 
price for the PCM is a challenging task. They considered an average price of 22.53 (US $\$ / \mathrm{m}^{2}$ ) for the purchase, transport, and installation of BioPCM with an equivalent thickness of $2.01 \mathrm{~cm}$. Saffari et al. [72] considered that the PCM cost is $0.62 € / \mathrm{kg}$ based on previous purchase and the cost of the installation of PCM is approximated as $4.36 € / \mathrm{m}^{2}$. The cost of purchasing and installing PCM was estimated at USD $2 / \mathrm{m}^{2}$ for a $10-\mathrm{mm}$ thick layer of PCM in [27] and [28]. Table 17 summarizes the price of some PCM reported in the literature.

Table 17: Cost of some phase change materials (data source [25], [26], [71] )

\begin{tabular}{lc}
\hline \multicolumn{1}{c}{ Material } & Cost (US\$/kg) \\
\hline Paraffin Wax (organic) & $1.88-2.00$ \\
Eicosane-technical grade (organic) & 7.04 \\
Eicosane-pure laboratory grade (organic) & 53.9 \\
Rubitherm (RT20) & 16.31 \\
Rubitherm (RT 23,25,27) & 0.68 \\
Stearic acid (fatty acid) & $1.43-1.56$ \\
Palmitic acid (fatty acid) & $1.61-1.72$ \\
Oleic acid (fatty acid) & $1.67-1.76$ \\
Crude Glycerin (fatty acid) & $0.22-0.29$ \\
M-27 (commercially available fatty acid) & 14.26 \\
M-51 (commercially available fatty acid) & 11.13 \\
Calcium chloride (inorganic-salt haydrates) & 0.20 \\
Latest ${ }^{\mathrm{TM}}$ 29T (commercially availabl2e salt hydrates) & 4.95 \\
BioPCM & 1.30 \\
\hline
\end{tabular}

In this study, following a discussion with 'PCM products Ltd' company [70], the price of the fatty acid product is approximated as $3.23 \$ / \mathrm{kg}$. An additional $60 \%$ was considered for the integration of PCM in the glass bricks and for the installation, and $25-35 \%$ of the total cost is added for labor cost. The average total PCM cost is thus about $54 \$ / \mathrm{m}^{2} / \mathrm{cm}$ in the investigated cities.

The PCM used in this study (fatty acids filled in glass bricks) has been already integrated in a real application in a full-sized test cell located at Sophia Antipolis within PERSEE center of Mines Paris Tech graduate school for 10 years (since 2008) [32]. Till now the PCM is still working, maintaining its thermophysical properties and changing its phase. Thus, it is possible to consider that a payback period of 10 years is acceptable in this study.

On the other hand, according to PCM manufacturing companies, fatty acids PCM (as RT28HC) are chemically stable, quite inert, and can therefore have a lifetime of a thousand years. Avoiding direct sun exposure, providing fresh air supply and avoiding overheating of the system could 
maintain the lifetime of the material. The lifetime is usually determined by other components than the PCM itself.

The lighting price is accounted for within the total life-cycle cost, when the artificial lighting is needed, and when its value is significant compared to heating and cooling loads prices. The European Lighting Standard EN12464-1 [36], requires an illuminance of 500 lux in working areas. In addition, according to IESNA Lighting Handbook [73] the recommended lighting level in offices is between 300 and 500 lux. Using a LED lamp, the illuminance of 300 - 500 lux corresponds to the power of $3.333 \mathrm{~W} / \mathrm{m}^{2}-5.555 \mathrm{~W} / \mathrm{m}^{2}$ respectively, i.e. $90-150 \mathrm{~W}$ for the considered office. Accordingly, the calculated total annual lighting load is $6.9 \mathrm{kWh} / \mathrm{m}^{2} /$ year to 11 $\mathrm{kWh} / \mathrm{m}^{2} /$ year. The TIM-PCM wall provides at a certain time useful daylighting without the need for the artificial lighting, thus the annual lighting load decreases with the increase of the TIMPCM wall area. The illuminance provided by the wall is approximated by the transmitted solar radiation and verified based on experimental measurements. For each climate, the number of occupied hours, where the daylighting is not sufficient (illuminance $<500$ Lux), is evaluated for each TIM-PCM wall surface area, and the cost of the needed artificial lighting is then calculated. The life cycle cost and the payback period are evaluated for both cases, TIM-PCM wall and conventional insulated double-glazed window, and the recommendation for each climate from an economic point of view will be discussed. In section 3, the optimum TIM-PCM wall area showing the best energy performance in each climate was determined as $7.53 \mathrm{~m}^{2}$ except in Sacramento (Csa). It's also necessary to find the optimum TIM-PCM wall area corresponding to minimum life cycle cost or minimum payback period in each climate. Figure 8 to Figure 12 show the initial cost, the heating and cooling consumption cost, the total cost, the energy savings cost, and the payback period for both cases for the different climates. From these figures, it can be noticed that the heating costs decrease, and cooling costs increase as the area of the TIM-PCM wall or the double-glazed window area increases. The initial cost varies almost linearly with the area. The total cost and payback period decrease to a certain minimum then start to increase in some cases. The optimum area is the one that ensures this minimum of the total cost or minimum payback period. For each climate, the optimum areas are presented in Table 18 and Table 19. In colder climates (Figure 8 and Figure 9), Barentsburg (ET) and Kiruna (Dfc), the use of TIMPCM wall is more cost-effective than the use of the double-glazed window, the optimum TIMPCM wall area providing minimum LCC and minimum PP being $7.532 \mathrm{~m}^{2}$. Due to the high 
heating loads in these climates and the relatively high natural gas prices and PWF, the total cost depends mainly on the heating costs and there is larger potential to reduce energy consumption costs through enlarging the TIM-PCM wall area. The minimum payback periods found are 10.5 years and 7.8 years in Barentsburg (ET) and Kiruna (Dfc) respectively, showing that the application of TIM-PCM wall is economically feasible in these climates. In these cities, the cost of lighting is neglected since it is marginal compared to heating costs.
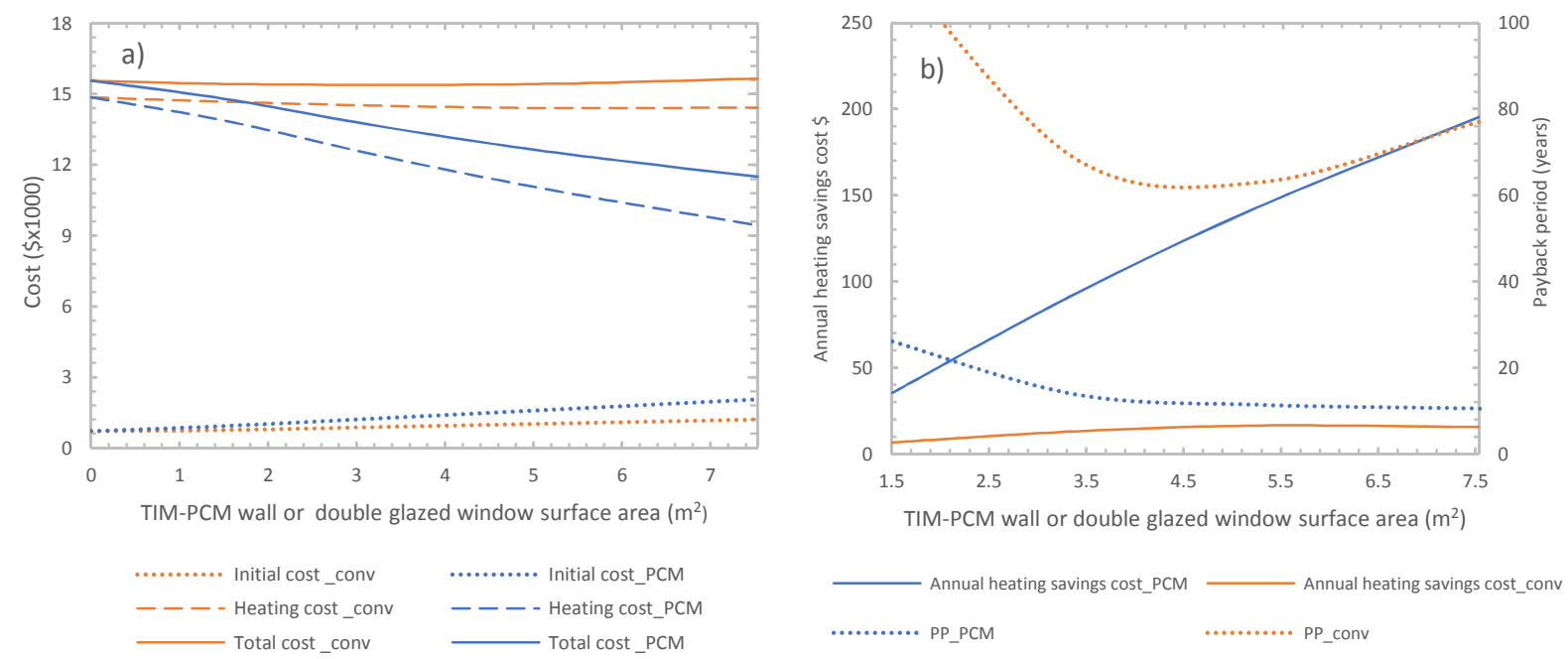

Figure 8: a) Life cycle cost and b) payback period for both cases for Barentsburg (ET)
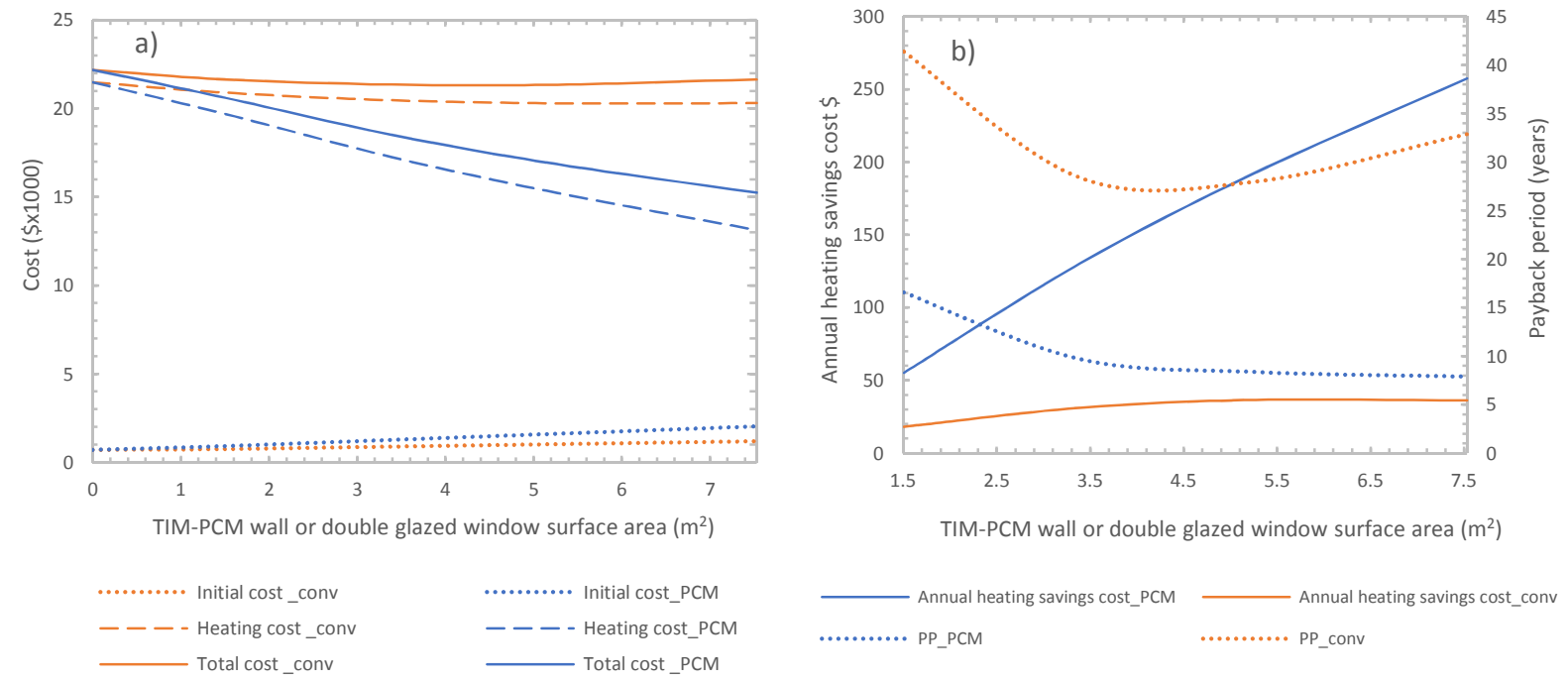

Figure 9: a) Life cycle cost and b) payback period for both cases for Kiruna (Dfc)

In Dras (Dsb), in spite of the high heating loads and energy savings due to the use of the TIMPCM wall, the double-glazed window proves to be more cost-effective than the TIM-PCM wall 
(Figure 10-a). The initial cost controls the total life-cycle cost due to the very low energy prices (2 cents/kWh for natural gas) and relatively low PWF (high discount rate). The optimum TIMPCM wall area is found $1.51 \mathrm{~m}^{2}$ with a minimum LCC of $2002 \$$ while the optimum doubleglazed window area is $2.45 \mathrm{~m}^{2}$ with a minimum LCC of $1892 \$$ (Table 18). Concerning the minimum payback period, it is found about 35 years for an optimum TIM-PCM wall area of 4.57 $\mathrm{m}^{2}$ (Table 19). The PP is relatively high because the cost of energy savings is insignificant compared to the initial cost, which makes the use of TIM-PCM wall economically unfeasible. Higher natural gas prices and lower PCM investment costs are required in Dras (India).
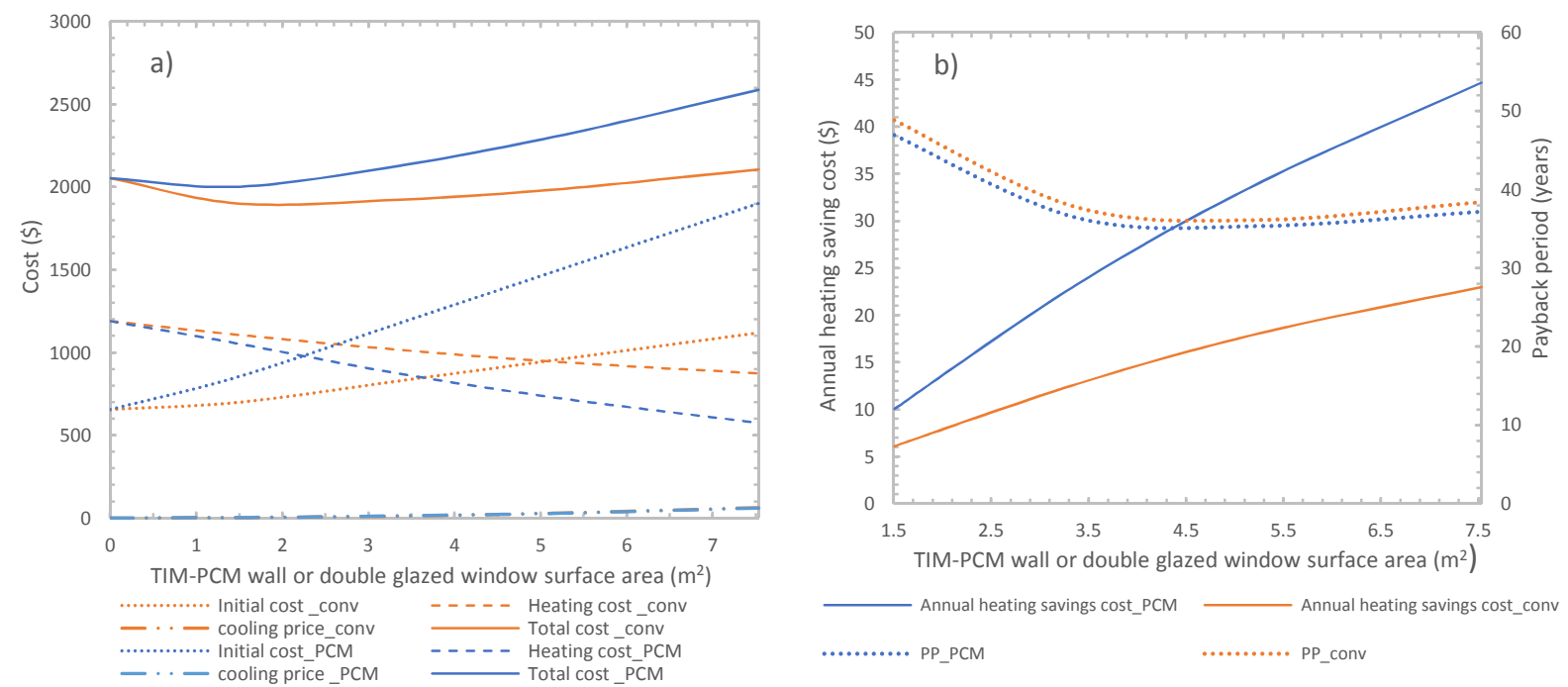

Figure 10: a) Life cycle cost and b) payback period for both cases for Dras (Dsb)

In Paris ( $\mathrm{Cfb})$, the use of TIM-PCM wall is more cost-effective than the use of the double-glazed window, giving lower LCC and PP (Figure 11). The optimum TIM-PCM wall area is found $5 \mathrm{~m}^{2}$ with minimum LCC of 4100 \$ (Table 18). Concerning the payback period, the minimum value is found 22 years corresponding to $3.87 \mathrm{~m}^{2}$ (Table 19). To be more economically feasible, the reduction of the initial cost of the TIM-PCM wall is needed in Paris (France). 

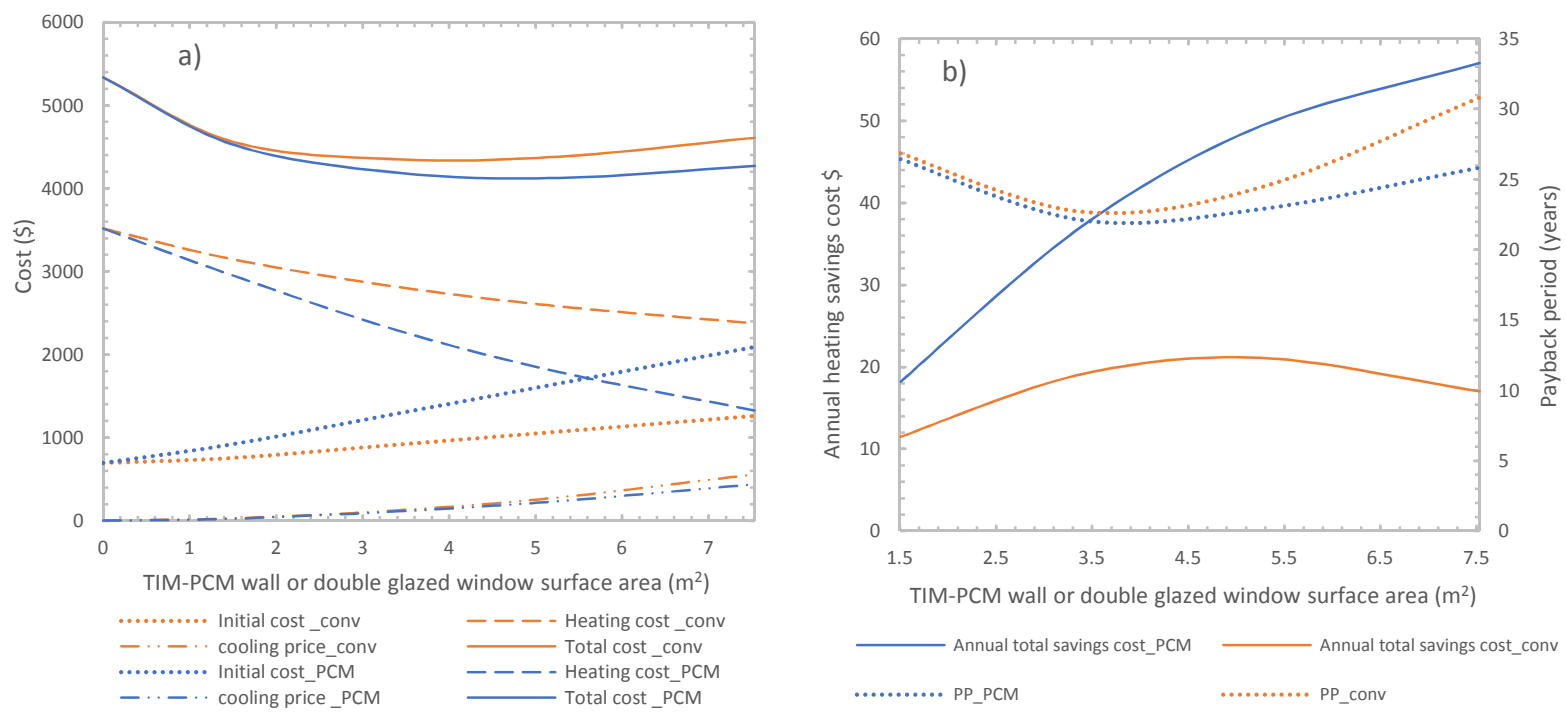

Figure 11: a) Life cycle cost and b) payback period for both cases for Paris (Cfb)

In Sacramento (Csa) and Toronto (Dfa) having a hot summer season (Figure 12), the use of double-glazed window is more efficient economically than the use of the TIM-PCM wall. In Sacramento (Csa), the optimum TIM-PCM wall area is found $1.5 \mathrm{~m}^{2}$ with a minimum LCC of $1833 \$$ while the optimum double-glazed window area is found $1.5 \mathrm{~m}^{2}$ with a minimum LCC of 1675 \$ (Table 18). In Toronto (Dfa), the heating savings cost is low due to the low natural gas prices in Canada (1.1 cents/ $\mathrm{kWh}$ ), which makes the total cost depending mainly on the initial cost. The optimum TIM-PCM wall area is found $1.51 \mathrm{~m}^{2}$ with a minimum LCC of $2106 \$$ while the optimum double-glazed window area is $1.5 \mathrm{~m}^{2}$ with a minimum LCC of 1988 (Table 18). Concerning the minimum payback period, the investment cost of the TIM-PCM wall can be recovered in Sacramento after 45 years and in Toronto after 51 years (Table 19), which makes the application of such a wall economically unfeasible and not recommended in such climates. 

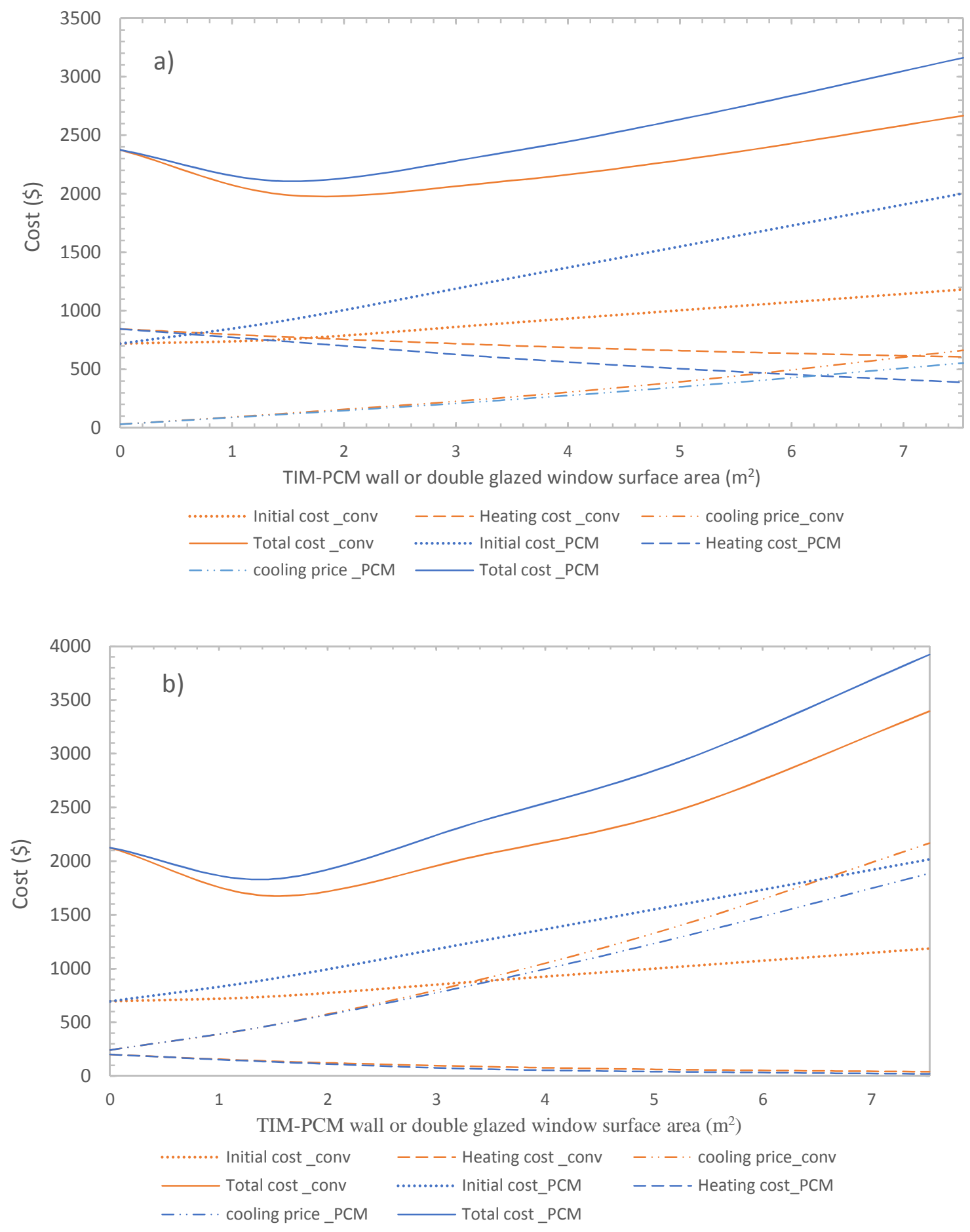

Figure 12: Life cycle cost for a) Toronto (Dfa) and b) Sacramento (Csa)

Table 18: Minimum life cycle cost and optimum area of the TIM-PCM wall and the double-glazed window in each climate

Double-glazed window $\quad$ TIM-PCM wall

Minimum LCC (\$) Optimum area $\left(\mathrm{m}^{2}\right) \quad$ Minimum LCC $(\$) \quad$ Optimum area 


\begin{tabular}{ccccc}
\hline & & & $\left(\mathrm{m}^{2}\right)$ \\
\hline Barentsburg (ET) & 15384 & 3.28 & 11494 & 7.532 \\
Kiruna (Dfc) & 21317 & 4.22 & 15240 & 7.532 \\
Dras (Dsb) & 1892 & 2.45 & 2002 & 1.51 \\
Toronto (Dfa) & 1988 & 1.5 & 2106 & 1.51 \\
Paris $(\mathrm{Cfb})$ & 4188 & 3.48 & 4100 & 5 \\
Sacramento $(\mathrm{Csa})$ & 1675 & 1.5 & 1833 & 1.5 \\
\hline
\end{tabular}

Table 19: Minimum payback period and optimum area of the TIM-PCM wall and the double-glazed window in each climate

\begin{tabular}{ccccc}
\hline & \multicolumn{2}{c}{ Double-glazed window } & \multicolumn{2}{c}{ TIM-PCM wall } \\
\hline & $\begin{array}{c}\text { Minimum PP } \\
\text { (years) }\end{array}$ & $\begin{array}{c}\text { Optimum area } \\
\left(\mathrm{m}^{2}\right)\end{array}$ & Minimum PP (years) & $\begin{array}{c}\text { Optimum area } \\
\left(\mathrm{m}^{2}\right)\end{array}$ \\
\hline Barentsburg (ET) & 61.72 & 4.63 & 10.51 & 7.532 \\
Kiruna (Dfc) & 27.11 & 4.34 & 7.87 & 7.532 \\
Dras (Dsb) & 35.95 & 4.75 & 35 & 4.57 \\
Toronto (Dfa) & 48.66 & 1.51 & 51.1 & 1.51 \\
Paris(Cfb) & 22.69 & 3.88 & 22 & 3.87 \\
Sacramento (Csa) & 31.3 & 1.51 & 43.26 & 1.51 \\
\hline
\end{tabular}

Moreover, in Toronto (Dfa) and Sacramento (Csa), the use of external Venetian blinds with an estimated price of $40 \$ / \mathrm{m}^{2}$ [74], [75] added to the initial cost, has no effect on the life cycle cost and slightly decreases the minimum payback period. In Sacramento (Csa), the use of doubleglazed window still more cost-effective than the use of the TIM-PCM wall and do not offer economic benefits in such a climate.

\section{Conclusion}

In this work, energy and economic analysis of the application of a TIM-PCM wall on a typical office building envelope was investigated under different climates for a whole year. The results showed that, in all studied climates, the energy performance of the office, in terms of heating and cooling savings, can be significantly improved with the incorporation of the TIM-PCM wall instead of a conventional insulated double-glazed window. In addition, the total loads decrease with the increase of the area of the TIM-PCM wall except in Mediterranean climate. From an economic point of view, the following conclusions can be drawn:

- In ET and Dfc climates, the application of TIM-PCM wall is economically feasible.

- In general, when the climate gets colder, the optimum TIM-PCM wall area increases. 
- The heating savings for the office building located in Dras (Dsb) are not sufficient to recover the investment, due to the low energy prices and high discount rates.

- In Paris (Cfb), the use of the TIM-PCM wall is found more cost effective than the use of double-glazed window in terms of minimum life-cycle cost and payback period.

- In Csa and Dfa climates, the TIM-PCM wall is not cost-effective at current energy and investment prices.

- The best candidates for the TIM-PCM wall application are found where energy prices for heating (natural gas in our study) are relatively high, making the initial capital cost relatively insignificant compared to the heating savings cost.

- The economic viability of the application of the TIM-PCM wall depends on different factors, mainly climatic conditions, energy savings, energy costs (natural gas prices, electricity prices, etc.), the economic situation of the country (discount rate) and investment costs.

Finally, further research should focus on the development of industrially scalable low-cost PCM, to decrease investment costs for buildings integrating such walls and as result make them economically viable. 


\section{References}

[1] B. Hojjati and S. H. Wade, "US household energy consumption and intensity trends: a decomposition approach," Energy Policy, vol. 48, pp. 304-314, 2012.

[2] F. Kuznik, D. David, K. Johannes, and J.-J. Roux, "A review on phase change materials integrated in building walls," Renew. Sustain. Energy Rev., vol. 15, no. 1, pp. 379-391, Jan. 2011.

[3] F. Ascione, N. Bianco, R. F. De Masi, F. de' Rossi, and G. P. Vanoli, "Energy refurbishment of existing buildings through the use of phase change materials: Energy savings and indoor comfort in the cooling season," Appl. Energy, vol. 113, pp. 990-1007, Jan. 2014.

[4] M. Alam, H. Jamil, J. Sanjayan, and J. Wilson, "Energy saving potential of phase change materials in major Australian cities," Energy Build., vol. 78, pp. 192-201, Aug. 2014.

[5] F. Souayfane, F. Fardoun, and P.-H. Biwole, "Phase change materials (PCM) for cooling applications in buildings: A review," Energy Build., vol. 129, pp. 396-431, Oct. 2016.

[6] R. Baetens, B. P. Jelle, and A. Gustavsen, "Phase change materials for building applications: A stateof-the-art review," Energy Build., vol. 42, no. 9, pp. 1361-1368, Sep. 2010.

[7] F. Kuznik, J. Virgone, and J. Noel, "Optimization of a phase change material wallboard for building use," Appl. Therm. Eng., vol. 28, no. 11-12, pp. 1291-1298, Aug. 2008.

[8] N. Soares, A. R. Gaspar, P. Santos, and J. J. Costa, "Multi-dimensional optimization of the incorporation of PCM-drywalls in lightweight steel-framed residential buildings in different climates," Energy Build., vol. 70, pp. 411-421, Feb. 2014.

[9] M. Saffari, A. de Gracia, C. Fernández, and L. F. Cabeza, "Simulation-based optimization of PCM melting temperature to improve the energy performance in buildings," Appl. Energy, vol. 202, pp. 420-434, Sep. 2017.

[10] H. J. Akeiber, S. E. Hosseini, H. M. Hussen, M. A. Wahid, and A. T. Mohammad, "Thermal performance and economic evaluation of a newly developed phase change material for effective building encapsulation," Energy Convers. Manag., vol. 150, pp. 48-61, Oct. 2017.

[11] M. Telkes, "Trombe wall with phase change storage material," in Proceedings of the 2nd National Passive Solar Conference, Philadelphia, PA, USA., 1978.

[12] F. Fiorito, "Trombe walls for lightweight buildings in temperate and hot climates. exploring the use of phase-change materials for performances improvement.," Energy Procedia, vol. 30, pp. 11101119, 2012.

[13] L. Zalewski, A. Joulin, S. Lassue, and Y. Dutil, "Experimental study of small-scale solar wall integrating phase change material," Sol. Energy, no. 86, pp. 208-219, 2012.

[14] A. de Gracia, L. Navarro, A. Castell, A. Ruiz-Pardo, S. Alvarez, and L. F. Cabeza, "Experimental study of a ventilated facade with PCM during winter period," Energy Build., pp. 58, 324-332, 2013.

[15] L. Yongcai and L. Shuli, "Experimental study on thermal performance of a solar chimney combined with PCM," Appl. Energy 114, pp. 172-178, 2014.

[16] F. Goia, M. Perino, and V. Serra, "Experimental analysis of the energy performance of a full-scale PCM glazing prototype," Sol. Energy, vol. 100, pp. 217-233, 2014.

[17] B. L. Gowreesunker, S. B. Stankovic, S. A. Tassou, and P. A. Kyriacou, "Experimental and numerical investigations of the optical and thermal aspects of a PCM-glazed unit," Energy Build., vol. 61, pp. 239-249, Jun. 2013.

[18] S. Li, G. Sun, K. Zou, and X. Zhang, "Experimental research on the dynamic thermal performance of a novel triple-pane building window filled with PCM," Sustain. Cities Soc., vol. 27, pp. 15-22, Nov. 2016.

[19] S. Grynning, F. Goia, and B. Time, "Dynamic Thermal Performance of a PCM Window System: Characterization Using Large Scale Measurements," Energy Procedia, vol. 78, pp. 85-90, Nov. 2015. 
[20] H. Manz, P. . Egolf, P. Suter, and A. Goetzberger, "TIM-PCM external wall system for solar space heating and daylighting," Sol. Energy, vol. 61, no. 6, pp. 369-379, Dec. 1997.

[21] T. Silva, R. Vicente, and F. Rodrigues, "Literature review on the use of phase change materials in glazing and shading solutions," Renew. Sustain. Energy Rev., vol. 53, pp. 515-535, Jan. 2016.

[22] E. Kyriaki, C. Konstantinidou, E. Giama, and A. M. Papadopoulos, "Life cycle analysis (LCA) and life cycle cost analysis (LCCA) of phase change materials (PCM) for thermal applications: A review," Int. J. Energy Res., Nov. 2017.

[23] A. Baniassadi, B. Sajadi, M. Amidpour, and N. Noori, "Economic optimization of PCM and insulation layer thickness in residential buildings," Sustain. Energy Technol. Assess., vol. 14, pp. 92-99, Apr. 2016.

[24] G. P. Panayiotou, S. A. Kalogirou, and S. A. Tassou, "Evaluation of the application of Phase Change Materials (PCM) on the envelope of a typical dwelling in the Mediterranean region," Renew. Energy, vol. 97, pp. 24-32, Nov. 2016.

[25] J. Kosny, N. Shukla, and A. Fallahi, "Cost analysis of simple phase change material-enhanced building envelopes in southern U.S. climates," Fraunhofer CSE: U. S. Department of Energy, Tech. rep., 2013.

[26] Ashley Bland, Martin Khzouz, Thomas Statheros, and Evangelos Gkanas, "PCMs for Residential Building Applications: A Short Review Focused on Disadvantages and Proposals for Future Development," Buildings, vol. 7, no. 3, p. 78, Aug. 2017.

[27] A. L. S. Chan, "Energy and environmental performance of building façades integrated with phase change material in subtropical Hong Kong," Energy Build., vol. 43, no. 10, pp. 2947-2955, Oct. 2011.

[28] X. Mi, R. Liu, H. Cui, S. A. Memon, F. Xing, and Y. Lo, "Energy and economic analysis of building integrated with PCM in different cities of China," Appl. Energy, vol. 175, pp. 324-336, Aug. 2016.

[29] M. A. Wahid, S. E. Hosseini, H. M. Hussen, H. J. Akeiber, S. N. Saud, and A. T. Mohammad, "An overview of phase change materials for construction architecture thermal management in hot and dry climate region," Appl. Therm. Eng., vol. 112, pp. 1240-1259, Feb. 2017.

[30] X. Sun, Q. Zhang, M. A. Medina, and K. O. Lee, "Energy and economic analysis of a building enclosure outfitted with a phase change material board (PCMB)," Energy Convers. Manag., vol. 83, pp. 73-78, Jul. 2014.

[31] N. Chaiyat, "Energy and economic analysis of a building air-conditioner with a phase change material (PCM)," Energy Convers. Manag., vol. 94, pp. 150-158, Apr. 2015.

[32] Y. Berthou, P. H. Biwole, P. Achard, H. Sallée, M. Tantot-Neirac, and F. Jay, "Full scale experimentation on a new translucent passive solar wall combining silica aerogels and phase change materials," Sol. Energy, vol. 115, pp. 733-742, May 2015.

[33] F. Souayfane, P. H. Biwole, and F. Fardoun, "Melting of a phase change material in presence of natural convection and radiation: A simplified model," Appl. Therm. Eng., vol. 130, pp. 660-671, Feb. 2018.

[34] Patry, Pierre-Manuel, and Dimitri Molle. RT 2012 et RT existant: Réglementation thermique et efficacité énergétique. Editions Eyrolles, 2015. .

[35] Handbook, ASHRAE Fundamentals. "American society of heating, refrigerating and air-conditioning engineers." Inc.: Atlanta, GA, USA (2009). .

[36] "European Lighting Standard EN12464-1." [Online]. Available: https://www.fagerhult.com/knowledge-hub/EN-12464-1/. [Accessed: 13-Feb-2018].

[37] M. Kottek, J. Grieser, C. Beck, B. Rudolf, and F. Rubel, "World Map of the Köppen-Geiger climate classification updated," Meteorol. Z., vol. 15, no. 3, pp. 259-263, Jun. 2006.

[38] F. Goia, M. Perino, and M. Haase, "A numerical model to evaluate the thermal behaviour of PCM glazing system configurations," Energy Build., vol. 54, pp. 141-153, Nov. 2012. 
[39] H. Elarga, F. Goia, A. Zarrella, A. Dal Monte, and E. Benini, "Thermal and electrical performance of an integrated PV-PCM system in double skin façades: A numerical study," Sol. Energy, vol. 136, pp. 112-124, 2016.

[40] G. Fraisse, "Development of a simplified and accurate building model based on electrical analogy," Energy \& Buildings, vol. 34, pp. 1017-1031, 2002.

[41] F. Souayfane, P. H. Biwole, and F. Fardoun, "Thermal behavior of a translucent superinsulated latent heat energy storage wall in summertime," Appl. Energy, vol. 217, pp. 390-408, May 2018.

[42] V. Voller, "Fast implicit finite-difference method for the analysis of phase change problems," Numer Heat Transfer Part B, pp. 17:155-69, 1990.

[43] R. Siegel, "Net radiation method for enclosure systems involving partially transparent walls," 1973.

[44] B. Zivkovic and I. Fujii, "An analysis of isothermal phase change of phase change material within rectangular and cylindrical containers," Sol. Energy, vol. 70, no. 1, pp. 51-61, 2001.

[45] F. Souayfane, P. H. Biwole, and F. Fardoun, "Modèle simplifié pour la prise en compte de la convection naturelle dans la modélisation du changement de phase solide-liquide," presented at the Colloque Inter-universitaire Franco-Québecois, Saint-lo, France, 2017.

[46] G. Vidalain, L. Gosselin, and M. Lacroix, "An enhanced thermal conduction model for the prediction of convection dominated solid-liquid phase change," Int. J. Heat Mass Transf., vol. 52, no. 7-8, pp. 1753-1760, Mar. 2009.

[47] P. Jany and A. Bejan, "Scaling theory of melting with natural convection in an enclosure," Int. J. Heat Mass Transf., vol. 31, no. 6, pp. 1221-1235, Jun. 1988.

[48] A. Bejan, Convection heat transfer, Fourth edition. Hoboken, New Jersey: Wiley, 2013.

[49] X. Faure, "Enveloppe hybride pour bâtiment à haute performance énergétique," Université JosephFourier-Grenoble I, 2007.

[50] W. Swinbank, "Long-wave radiation from clear skies," Q. J. R. Meteoro. Soc, p. 89:339, 1963.

[51] F. Miranville, "Contribution à l'étude des parois complexes en physique du bâtiment: modélisation, expérimentation et validation expérimentale de complexes de toitures incluant des produits minces réfléchissants en climat tropical humide," Université de la Réunion, 2002.

[52] S. V. Patankar, Numerical heat transfer and fluid flow. New York: McGraw-Hill., 1980.

[53] M. Ibrahim, P. H. Biwole, P. Achard, E. Wurtz, and G. Ansart, "Building envelope with a new aerogel-based insulating rendering: Experimental and numerical study, cost analysis, and thickness optimization," Appl. Energy, vol. 159, pp. 490-501, Dec. 2015.

[54] A. Kylili and P. A. Fokaides, "Life Cycle Assessment (LCA) of Phase Change Materials (PCMs) for building applications: A review," J. Build. Eng., vol. 6, pp. 133-143, Jun. 2016.

[55] M. Krarti and P. Ihm, "Evaluation of net-zero energy residential buildings in the MENA region," Sustain. Cities Soc., vol. 22, pp. 116-125, Apr. 2016.

[56] "Percentage of cost breakdown between labour, materials and contractor profit in construction." [Online]. Available: http://www.a4architect.com/2013/04/percentage-of-cost-breakdownbetween-labour-materials-and-contractor-profit-in-construction/. [Accessed: 15-Jan-2018].

[57] F. Fardoun, M. Hajjar, and H. Fardoun, "Heat pump designing and optimization tool," in 2009 International Conference on Advances in Computational Tools for Engineering Applications, Beirut, Lebanon, 2009, pp. 315-319.

[58] "K.A. Joudi and H.N.H. Namik, 'Component matching of a simple vapor compression refrigeration system,' Energy Conversion and Management 44 (2003) pp. 975-993."

[59] "P. Techarungpaisan, S. Theerakulpisut, and S. Priprem, 'Modeling of a split type air conditioner with integrated water heater,' Energy Conversion and Management 48 (2007) pp. 1222-1237."

[60] "Global electricity prices by select countries in 2017 (in U.S. dollars per kilowatt hour)." [Online]. Available: https://www.statista.com/statistics/263492/electricity-prices-in-selected-countries/. [Accessed: 15-Jan-2018]. 
[61] "Electricity prices for households in Norway from 2010 to 2016, semi-annually (in euro cents per kilowatt-hour)." [Online]. Available: https://www.statista.com/statistics/643369/electricity-pricesfor-households-in-norway/. [Accessed: 15-Jan-2018].

[62] Eurostat, "Electricity and natural gas price statistics." [Online]. Available: http://ec.europa.eu/eurostat/documents/38154/41386/SEarticle2012S1.pdf/364a98b3-648f-4716b95a-71484f430a9f. [Accessed: 15-Jan-2018].

[63] "Estimated landed prices of LNG worldwide as of May 2017, by select country (in U.S. dollars per million British thermal units)." [Online]. Available: https://www.statista.com/statistics/252984/landed-prices-of-liquefied-natural-gas-in-selectedregions-worldwide/. [Accessed: 15-Jan-2018].

[64] Eurostat, "Natural gas price statistics." [Online]. Available: http://ec.europa.eu/eurostat/statisticsexplained/index.php/Natural_gas_price_statistics. [Accessed: 15-Jan-2018].

[65] "Worldwide Central Bank Rates." [Online]. Available: http://www.cbrates.com/. [Accessed: 15-Jan2018].

[66] "Country comparison: Central Bank Discount Rate." [Online]. Available: https://www.cia.gov/library/publications/the-world-factbook/rankorder/2207rank.html. [Accessed: 15-Jan-2018].

[67] "Concrete price considerations- cost of concrete." [Online]. Available: https://www.concretenetwork.com/concrete-prices.html. [Accessed: 15-Jan-2018].

[68] "plasterboard installation." [Online]. Available: https://www.ato.gov.au/Business/Small-businessbenchmarks/In-detail/Benchmarks-A-Z/L-Q/Plastering-and-ceiling-services/?page=4. [Accessed: 15Jan-2018].

[69] "glass wool price list." [Online]. Available: https://www.alibaba.com/showroom/glass-wool-pricelist.html. [Accessed: 15-Jan-2018].

[70] "PCM Products." [Online]. Available: http://www.pcmproducts.net/Phase_Change_Material_Products.htm. [Accessed: 15-Jan-2018].

[71] Y. Cascone, A. Capozzoli, and M. Perino, "Optimisation analysis of PCM-enhanced opaque building envelope components for the energy retrofitting of office buildings in Mediterranean climates," Appl. Energy, vol. 211, pp. 929-953, Feb. 2018.

[72] M. Saffari, A. de Gracia, S. Ushak, and L. F. Cabeza, "Economic impact of integrating PCM as passive system in buildings using Fanger comfort model," Energy Build., vol. 112, pp. 159-172, Jan. 2016.

[73] "Recommended Lighting Levels in Buildings- IESNA Lighting Handbook." [Online]. Available: https://www.archtoolbox.com/materials-systems/electrical/recommended-lighting-levels-inbuildings.html. [Accessed: 13-Feb-2018].

[74] "Wholesale Pricing on Blinds and Shades." [Online]. Available: http://www.blindsmax.com/blog/how-much-do-new-blinds-cost/. [Accessed: 13-Feb-2018].

[75] "wide venetian blinds prices." [Online]. Available: http://wideblinds.co.uk/price_guide.html. [Accessed: 13-Feb-2018]. 